\title{
Supresja odporności podstawowej typu PTI przez syntetyzowane w fitopatogenach białka efektorowe wprowadzane do wnętrza komórek infekowanej rośliny
}

\section{Anna Hetmann ${ }^{\bowtie}$ \\ Stanisław Kowalczyk}

Zakład Biochemii, Wydział Biologii i Ochrony Środowiska, Uniwersytet M. Kopernika w Toruniu

$\llbracket$ Zakład Biochemii, Wydział Biologii i Ochrony Środowiska, Uniwersytet Mikołaja Kopernika, ul. Lwowska 1, 87-100 Toruń; tel.: (56) 61126 95, e-mail: ahetmann@umk.pl

Artykuł otrzymano 14 grudnia 2018 r. Artykuł zaakceptowano 28 stycznia 2019 r.

https://doi.org/10.18388/pb.2019_257

Słowa kluczowe: białka efektorowe fitopatogenów, tłumienie odporności podstawowej roślin, podatność rośliny na infekcję, immunoreceptory NB-LRR/NLR

Wykaz skrótów: ETI (ang. Effector-Triggered Immunity) - odporność aktywowana przez efektor; ETS (ang. Effector-Triggered Susceptibility) - podatność na infekcję wywoływana przez efektor; NB-LRR (ang. Nucleotide-Binding-Leucine-Rich Repeat) - immunoreceptor wewnątrzkomórkowy roślin rozpoznający białko efektorowe fitopatogena; NLR (ang. NOD-Like Receptor) - receptor wewnątrzkomórkowy podobny do receptorów NOD1 i 2 człowieka; PRR (ang. Pattern Recognition Receptor) - receptor błonowy rozpoznający określony wzorzec molekularny obcej bądź własnej cząsteczki; PTI (ang. PAMP-Triggered Immunity) - odporność aktywowana przez cząsteczkę MAMP/ PAMP i DAMP

\section{STRESZCZENIE}

$\mathbf{U}$ kład odpornościowy roślin obejmuje dwa, powiązane ze sobą poziomy obrony lokalnej. Pierwszą linię obrony (PTI) aktywują cząsteczki MAMP/PAMP i DAMP rozpoznawane przez zlokalizowane w błonie plazmatycznej białka receptorowe typu PRR. Jednakże fitopatogeny syntetyzują i wprowadzają do komórek rośliny gospodarza białka efektorowe wykorzystujące wspólne, ale także swoiste dla różnych fitopatogenów strategie molekularne nakierowane na supresję układu odpornościowego. Wiele białek efektorowych atakuje receptory PRR bądź białkowe i niebiałkowe elementy szlaków sygnałowych, inne zakłócają ważne procesy komórkowe, w tym m. in.: ubikwitylację i degradację białek w proteasomach, transport pęcherzykowy, reoorganizację cytoszkieletu, funkcjonowanie chloroplastów i mitochondriów, biosyntezę fitohormonów i przekazywanie sygnałów hormonalnych, ekspresję genów. Efektem tłumienia reakcji odpornościowych przez białka efektorowe jest wzrost podatności rośliny na infekcję ETS (ang. Effector-Triggered Susceptibility to infection) sprzyjający przeżywaniu i namnażaniu fitopatogena. W odpowiedzi na syntetyzowane przez fitopatogeny białka efektorowe, rośliny wykształciły w toku ewolucji immunoreceptory wewnątrzkomórkowe NB-LRR/NLR rozpoznające w sposób bezpośredni lub częściej w sposób pośredni wprowadzane do wnętrza komórek białka efektorowe. Zmiany konformacyjne w immunoreceptorze NB-LRR/NLR, towarzyszące rozpoznaniu białka efektorowego, aktywują wewnątrzkomórkowe szlaki sygnałowe uruchamiające cały wachlarz odpowiedzi obronnych typu ETI (ang. Effector-Triggered Immunity) stanowiących drugą linię obrony lokalnej.

\section{WPROWADZANIE}

W strategii obronnej roślin, odporność aktywowana przez cząsteczki typu MAMP/PAMP i DAMP stanowi pierwszą linię obrony, która nie tylko zapobiega infekcjom, ale także aktywnie zwalcza pojawiające się w roślinie fitopatogeny. Odporność podstawową, nazywaną odpornością typu PTI (ang. PAMP-Triggered Immunity), współtworzą reakcje obronne, w tym $\mathrm{m}$. in.: produkcja w apoplaście aktywnych form tlenu, zamykanie aparatów szparkowych, synteza i odkładanie w ścianach komórkowych kalozy, biosynteza fitoaleksyn, synteza białek typu PR (ang. Pathogenesis-Related) i peptydów antybakteryjnych, biosynteza fitohormonów związanych z odpornością, przeprogramowanie ekspresji tysięcy genów. Odporność typu PTI jest wystarczająco efektywna, by skutecznie chronić roślinę przez infekcjami i przeciwdziałać rozwojowi chorób. W pracy opublikowanej niedawno w Postępach Biochemii podsumowano wyniki dotychczasowych badań poświęconych identyfikowaniu cząsteczek typu MAMP/PAMP i DAMP, poznawaniu receptorów błonowych typu PRR (ang. Pattern Recognition Receptor) rozpoznających te cząsteczki i aktywujących wewnątrzkomórkowe szlaki sygnałowe inicjujące odporność lokalną PTI [1]. Jednakże w toku ewolucji organizmy patogenne wykształciły szereg mechanizmów molekularnych umożliwiających przełamywanie pierwszej linii obrony, a w efekcie sprzyjających kolonizacji rośliny. W tłumieniu odporności PTI, fitopatogeny z różnych grup systematycznych wykorzystują specjalne białka oraz wiele różnych małych cząsteczek nazywanych ogólnie efektorami, które w różny sposób uczestniczą $\mathrm{w}$ opanowaniu rośliny. Ostatecznie, supresja reakcji odpornościowych prowadzi do wzrostu podatności rośliny na infekcję ETS (ang. Effector-Triggered Susceptibility to infection) umożliwiającej przeżywanie i namnażanie fitopatogena [2]. W tym miejscu należy wyraźnie podkreślić, że w literaturze naukowej termin efektor używany jest $\mathrm{w}$ podwójnym znaczeniu. $\mathrm{W}$ znaczeniu szerszym obejmuje on różne białka sekrecyjne, w tym również enzymy degradujące niektóre składniki komórek rośliny, ale także cząsteczki typu MAMP/PAMP oraz wiele innych substancji, $\mathrm{w}$ tym również toksyny produkowane przez różne fitopatogeny. $\mathrm{W}$ kolonizacji roślin przez biotroficzne i hemibiotroficzne grzyby i grzybopodobne lęgniowce (Oomycetes) szczególną rolę ogrywają efektory kierowane do apoplastu, zwłaszcza enzymy degradujące polisacharydy budujące ściany komórkowe, inhibitory różnych proteaz roślinnych, enzymy unieszkodliwiające fitoantycypiny i fitoaleksyny oraz cząsteczki, które zaburzają percepcję cząsteczek MAMP/ PAMP, np. syntetyzowane przez niektóre grzyby białka Ecp6, Slp1 z domenami 
LysM, które przechwytują chitooligosacharydy i przeciwdziałają $\mathrm{w}$ ten sposób aktywacji kompleksów receptorowych wiążących chitynę [3]. W odróżnieniu od tych białek i innych cząsteczek efektorowych, kierowanych głównie do apoplastu, w obecnej pracy termin efektor (białko efektorowe) jest używany w węższym znaczeniu, wyłącznie w odniesieniu do białek syntetyzowanych i wprowadzanych przez fitopatogeny do wnętrza komórek atakowanej rośliny [4]. Rozwój metod i technik biologii molekularnej pozwala obecnie identyfikować dziesiątki, a nawet setki białek efektorowych syntetyzowanych przez fitopatogeny, które w różny sposób są wprowadzane do komórek rośliny [5]. Bakterie Gram-ujemne wykorzystują w tym celu tzw. III system sekrecyjny TIIISS (ang. Type III protein Secretion System) [6]. W śledzeniu wnikania bakteryjnych białek efektorowych do komórek rośliny wykorzystywane są różne nowe techniki, w tym m. in. technika SFP (ang. Split Fluorescent Protein), która pozwala monitorować migrację białka efektorowego w komórkach różnych tkanek i organów, a także daje możliwość ustalenia jego ostatecznej lokalizacji subkomórkowej, co z kolei pomaga $\mathrm{w}$ identyfikowaniu potencjalnego celu ataku [7]. Białka efektorowe syntetyzowane przez biotroficzne i hemibiotroficzne grzyby i legniowce są wprowadzane do wnętrza komórek rośliny za pośrednictwem haustoriów (ssawek) służących do pobierania z rośliny substancji pokarmowych [8]. W tym wypadku białka efektorowe są wydzielane do przestrzeni zawartej pomiędzy błoną haustorium a błoną plazmatyczną komórki roślinnej, skąd następnie wnikają do wnętrza komórki na drodze endocytozy. W niektórych przypadkach białka efektorowe są wprowadzane do rośliny poprzez fuzję endosomów grzyba z błoną plazmatyczną komórek rośliny [8].

W tym miejscu warto jeszcze zwrócić uwagę, że białka efektorowe syntetyzują także nicienie z rodzaju guzaków (Meloidogyne), czy mątwikowatych (Globodera) [9], a także roślinożerne owady - gąsienice i chrząszcze [10] oraz pluskwiaki (mszyce, skoczki) [11-13].

Białka efektorowe wprowadzone do komórek rośliny przełamują reakcje odpornościowe, umożliwiając $\mathrm{w}$ ten sposób kolonizację rośliny. Tak się dzieje w przypadku roślin nie dysponujących odpowiednimi immunoreceptorami wewnątrzkomórkowymi, które mogą rozpoznawać swoiście poszczególne białka efektorowe (rośliny podatne na zakażenia). Jednakże rośliny, które w toku ewolucji wykształciły odpowiedni zestaw immunoreceptorów wewnątrzkomórkowych, mogą wykrywać w komórce obecność określonych białek efektorowych, co w konsekwencji daje możliwość uruchomienia całego wachlarza reakcji odpornościowych współtworzących drugą linię obrony lokalnej [2]. W swoistym rozpoznaniu białek efektorowych pośredniczą specjalne wewnątrzkomórkowe immunoreceptory R (ang. Resistance), które w ten sposób stają się pierwszymi ogniwami szlaków sygnałowych aktywujących odpowiedzi obronne typu ETI (ang. Effector-Triggered Immunity) [2,14]. Immunoreceptory wewnątrzkomórkowe są $\mathrm{w}$ zasadzie tożsame $\mathrm{z}$ produktami genów $R$, które $\mathrm{w}$ koncepcji Flora gen-na-gen sprzed ponad 70 lat miały oddziaływać z produktami genów awirulentnych (ang. avirulence) wywołujących w roślinach reakcje nadwrażliwości HR (ang. Hypersensitive Response) [4]. Dzisiaj już wiadomo, że reakcja typu HR jest programowaną śmiercią komórki, która pojawia się $\mathrm{w}$ miejscu infekcji u rośliny dysponującej odpowiednim immunoreceptorem $\mathrm{R}$ rozpoznającym swoiście określone białko Avr (roślina niepodatna na zakażenie). Oddziaływanie tego typu jest określane jako interakcja niekompatybilna. W przypadku, gdy roślina nie posiada immunoreceptora mogącego rozpoznać białko Avr (roślina podatna na zakażenie), białko efektorowe Avr funkcjonuje jako białko wirulentne (interakcja kompatybilna) [4]. Immunoreceptorami wewnątrzkomórkowymi typu R są białka z rodziny NB-LRR (ang. Nucleotide-Binding site, Leucine-Rich Repeat), które pod względem budowy są podobne do zwierzęcych, wewnątrzkomórkowych receptorów NLR (ang. NOD-Like Receptor) rozpoznających cząsteczki PAMP/DAMP [15-19]. Zmiany konformacyjne w immunoreceptorze NB-LRR będące efektem rozpoznania białka efektorowego wymuszają wymianę związanego $\mathrm{z}$ immunoreceptorem ADP na ATP, co ostatecznie prowadzi do utworzenia formy aktywnej immunoreceptora NB-LRR aktywującego szlaki sygnałowe uruchamiające reakcje obronne typu ETI $[18,20]$.

Celem obecnej pracy było podsumowanie najważniejszych osiągnięć w identyfikowaniu białek efektorowych syntetyzowanych przez patogenne bakterie, lęgniowce i grzyby oraz prześledzenie poznanych już mechanizmów molekularnych wykorzystywanych przez te białka w tłumieniu odporności typu PTI.

\section{BIAŁKA EFEKTOROWE FITOPATOGENÓW INGERUJĄCE W REAKCJE ODPORNOŚCIOWE I ZABURZAJĄCE WAŻNE PROCESY KOMÓRKOWE ROŚLIN}

Na wstępie warto zwrócić uwagę, że spośród poznanych dotychczas około 7100 gatunków bakterii, patogenami roślin jest około 150 gatunków [14], ale wiedza na temat białek efektorowych syntetyzowanych przez fitopatogeny bakteryjne pochodzi $\mathrm{z}$ badań patogennych szczepów zaledwie kilku gatunków. Na liście dziesięciu najważniejszych, z punktu widzenia ekonomicznego i badawczego, bakterii patogennych, aż sześć miejsc zajmują bakterie Gram-ujemne z czterech rodzajów, a mianowicie: Pseudomonas, Xanthomonas, Ralstonia i Erwinia [21]. Syntetyzowane przez te bakterie białka efektorowe są "wstrzykiwane” do wnętrza komórek atakowanej rośliny za pośrednictwem III systemu sekrecyjnego (TIIISS) zbudowanego z aparatu sekrecyjnego, pilusa i translokonu. Aparat sekrecyjny przenika przez obie błony bakteryjne, a pilus, przypominający igłę strzykawkową, łączy aparat sekrecyjny $\mathrm{z}$ translokonem wbudowującym się do błony plazmatycznej komórki roślinnej [6]. Identyfikowanie białek efektorowych syntetyzowanych przez bakterie na ogół nie nastręcza trudności, gdyż w części N-końcowej mają one szereg charakterystycznych motywów kierujących białka do układu sekrecyjnego [5]. Wytypowane w ten sposób potencjalne efektory, badane są następnie pod kątem ich ewentualnej aktywności enzymatycznej, docelowej lokalizacji subkomórkowej, poznawania białka/białek będącego celem ataku oraz identyfikowania immunoreceptorów NB-LRR rozpoznających badane białka [5]. W prowadzonych obecnie badaniach molekularnych uwaga 
badaczy koncentruje się głównie na białkach efektorowych kilku patogennych szczepów Pseudomonas syringae (Pst DC3000, Pss -pv. syringae, Pph - pv. phaseolicoloa i Pta -pv. tabaci), a także białkach syntetyzowanych przez kilka patogennych szczepów Xanthomonas (Xoo, Xact, Xcv, Xcc). Genomy wszystkich badanych szczepów P. syringae kodują łącznie 57 grup białek efektorowych, ale poszczególne szczepy syntetyzują od 15 do 35 białek [22,23]. Patogenne szczepy bakterii z rodzaju Xanthomonas syntetyzują w sumie około 40 grup białek efektorowych Xop/Hop [24]. Genomy patogennych szczepów Ralstonia solanacearum kodują 94 grupy białek Rip (ang. Ralstonia injected proteins), chociaż poszczególne szczepy syntetyzują 60-75 białek efektorowych, ale wszystkie szczepy syntetyzują zestaw 22 takich samych białek [25]. Przeprowadzone ostatnio analizy porównawcze 177 białek efektorowych pochodzenia bakteryjnego sugerują, że około $40 \%$ białek wprowadzanych do komórek rośliny kieruje się do błon, 31\% migruje do jądra, 24\% pozostaje w cytoplazmie, $2 \%$ wnika do chloroplastów, a tylko około $1 \%$ białek występuje w pozostałych strukturach subkomórkowych (mitochondriach, siateczce śródplazmatycznej, peroksysomach, wczesnych endosomach) [26]. W przypadku białek pochodzących z bakterii rodzaju Pseudomonas, Xanthomonas i Ralstonia proporcje te różnią się dosyć znacząco, bo np. około 52\% białek efektorowych syntetyzowanych przez bakterie Pseudomonas, wg autorów, kieruje się do błon, podczas gdy $45 \%$ białek Xanthomonas miałoby migrować do jądra, a 30\% do błon, natomiast około $50 \%$ białek pochodzacych z Ralstonia miałoby pozostawać w cytoplazmie [26]. Ponadto szacuje się, że około $68 \%$ białek efektorowych pochodzenia bakteryjnego atakuje w roślinie więcej niż jeden cel, z tego $36 \%$ oddziałuje z białkami z różnych klas, a 32\% z białkami jednej klasy i około $32 \%$ białek efektorowych wykazuje bezwzględną specyficzność, bowiem każde $\mathrm{z}$ nich atakuje tylko jedno określone białko [26].

Jak już wcześniej wspomniano, wiedza na temat białek efektorowych syntetyzowanych przez grzyby i lęgniowce jest jeszcze dosyć ograniczona, chociaż w ostatnich latach nastąpił pewien postęp, zwłaszcza w odniesieniu do białek efektorowych syntetyzowanych przez biotroficzne lęgniowce. Szacunkowa liczba fitopatogenów należących do tych dwóch grup systematycznych sięga około 8000 gatunków [14], ale liczba sklonowanych genów Avr wynosi obecnie około 40, z tego ponad połowa genów pochodzi z lęgniowców z rodzaju Phytopthora (P. infestans infekującego pomidory i ziemniaki oraz $P$. sojae infekującego soję) oraz Hyaloperonospora arabidopsis infekującego rzodkiewnika $[27,28]$. Identyfikowanie białek efektorowych syntetyzowanych przez lęgniowce ułatwia fakt, że wiele $\mathrm{z}$ nich posiada charakterystyczne motywy (RxLR-dEER, Crinkler motif (CRN), CHxC, LxLFLAK), które przypuszczalnie odgrywają pewną rolę $\mathrm{w}$ transporcie do wnętrza komórek rośliny. Analizy genomów trzech gatunków Phytophthora wykazały, że liczba genów kodujących białka z motywem RxLR mieści się w przedziale od 374 do 563 genów [28]. Białka efektorowe lęgniowców wprowadzone do rośliny kierują się głównie do jądra (38\%), a po około $17 \%$ białek migruje do błon, do peroksysomów i do siateczki śródplazmatycznej, a tylko 8\% pozostaje w cytoplazmie [26].
Poznane dotychczas białka efektorowe grzybów bio- i hemibiotroficznych pochodzą w większości z Magnaporthe oryzae wywołującego zarazę (plamicę) ryżu, z Leptosphaeria maculans powodującego zgniliznę kapustnych, z Melamspora linii infekującego len oraz z mączniaka prawdziwego zbóż i traw (Blumeria graminis), a więc gatunków, które na liście 10 najgroźniejszych grzybów patogennych zajmują miejsca czołowe [29]. Warto też zauważyć, że spośród 17 analizowanych białek efektorowych grzybów wprowadzanych do rośliny, około $61 \%$ pozostaje w cytoplazmie, $28 \%$ wnika do jądra, a 11\% migruje do błon [26].

Dzisiaj już wiadomo, że duża część białek efektorowych syntetyzowanych przez bakterie, grzyby i lęgniowce wykazuje aktywność enzymatyczną. Stosunkowo liczna grupa białek posiada aktywność acetylotransferazową (HopZ1a, HopZ3, HopZ4, AvrBsT, XopJ, PopP2). Szereg białek pochodzenia bakteryjnego (AvrPphB, AvrRpT2, HopN1, HopX1, AvrXccB) i kilka pochodzących z grzybów (Avr2, Pit2, EPIC1, EPIC2B) wykazuje aktywność proteaz cysteinowych [27,30]. Białka efektorowe AvrPtoB, XopL i XopK syntetyzowane przez bakterie są ligazami ubikwitynowymi E3, białka HopF2, HopU1 posiadają aktywność mono-ADP-rybozylotransferazy przenoszącej resztę adenozynodifosforybozy (ADP-rybozy) z NAD ${ }^{+}$na białko substratowe [30], a AvrAC/XopAC funkcjonuje jako urydynylotransferaza przenosząca resztę urydyno 5'-monofosforanu z UTP na białko docelowe [30,31].

Jak już wcześniej wspomniano, głównym celem ataku większości białek efektorowych syntetyzowanych przez fitopatogeny są różne białka układu odpornościowego roślin. Okazało się, że wiele z nich blokuje kompleksy receptorowe wiążące cząsteczki MAMP/PAMP, szereg białek efektorowych atakuje cytoplazmatyczne kinazy białkowe typu RLCK oraz kinazy białkowe funkcjonujące w kaskadach kinaz MAP oraz inne białkowe i niebiałkowe elementy szlaków sygnałowych aktywujących reakcje odpornościowe $[30,32,33]$. Ponadto wiele białek efektorowych ingeruje w ważne procesy komórkowe, bezpośrednio lub pośrednio powiązane z układem odpornościowym [34,35,36]. Wykazano, że niektóre z nich zakłócają funkcjonowanie układów ubikwitylacji i degradacji białek w proteasomach $[37,38]$, inne zaburzają transport peccherzykowy i ingerują $\mathrm{w}$ cytoszkielet [30,39]. Poznano też szereg białek efektorowych zakłócających funkcjonowanie chloroplastów i mitochondriów [39,40] oraz wpływających na biosyntezę fitohormonów i naruszających szlaki przekazywania sygnałów hormonalnych [41-43]. W ostatnim czasie rośnie też liczba danych świadczących o tym, że wiele białek efektorowych oddziałuje bezpośrednio z DNA bądź dezorganizuje funkcjonowanie czynników transkrypcyjnych [44-47].

W dwóch kolejnych podrozdziałach przedstawiono skrótowo mechanizmy molekularne, które są wykorzystywane przez białka efektorowe $\mathrm{w}$ tłumieniu reakcji odpornościowych i zaburzaniu różnych procesów komórkowych. Opis tych mechanizmów dotyczy jedynie tych białek, w przypadku których sposób działania został już stosunkowo dobrze poznany. 


\section{BLOKOWANIE RECEPTORÓW PRR I} MODYFIKOWANIE BIAŁKOWYCH I NIEBIAŁKOWYCH ELEMENTÓW SZLAKÓW SYGNAŁOWYCH

Już przed 10 laty odkryto, że 20 kDa białko efektorowe AvrPto syntetyzowane przez $P$. syringae, badane wcześniej w kontekście jego oddziaływań z kinazą białkową Pto pomidora, blokuje w pomidorze błonową kinazę receptorową LeFLS2, a $\mathrm{w}$ rzodkiewniku kinazy AtFLS2 i AtEFR wiążące flagelinę i czynnik elongacyjny EF-Tu bakterii [1,23,30,32,33]. Oddziaływanie AvrPto z domeną kinazową powoduje, że fosforylowanie odpowiednich reszt serynowych/treoninowych położonych w obrębie tej domeny staje się niemożliwe, co w efekcie prowadzi do blokowania transdukcji sygnału na cytoplazmatyczne kinazy RLCK (Ryc. 1). W ostatnim czasie odkryto,

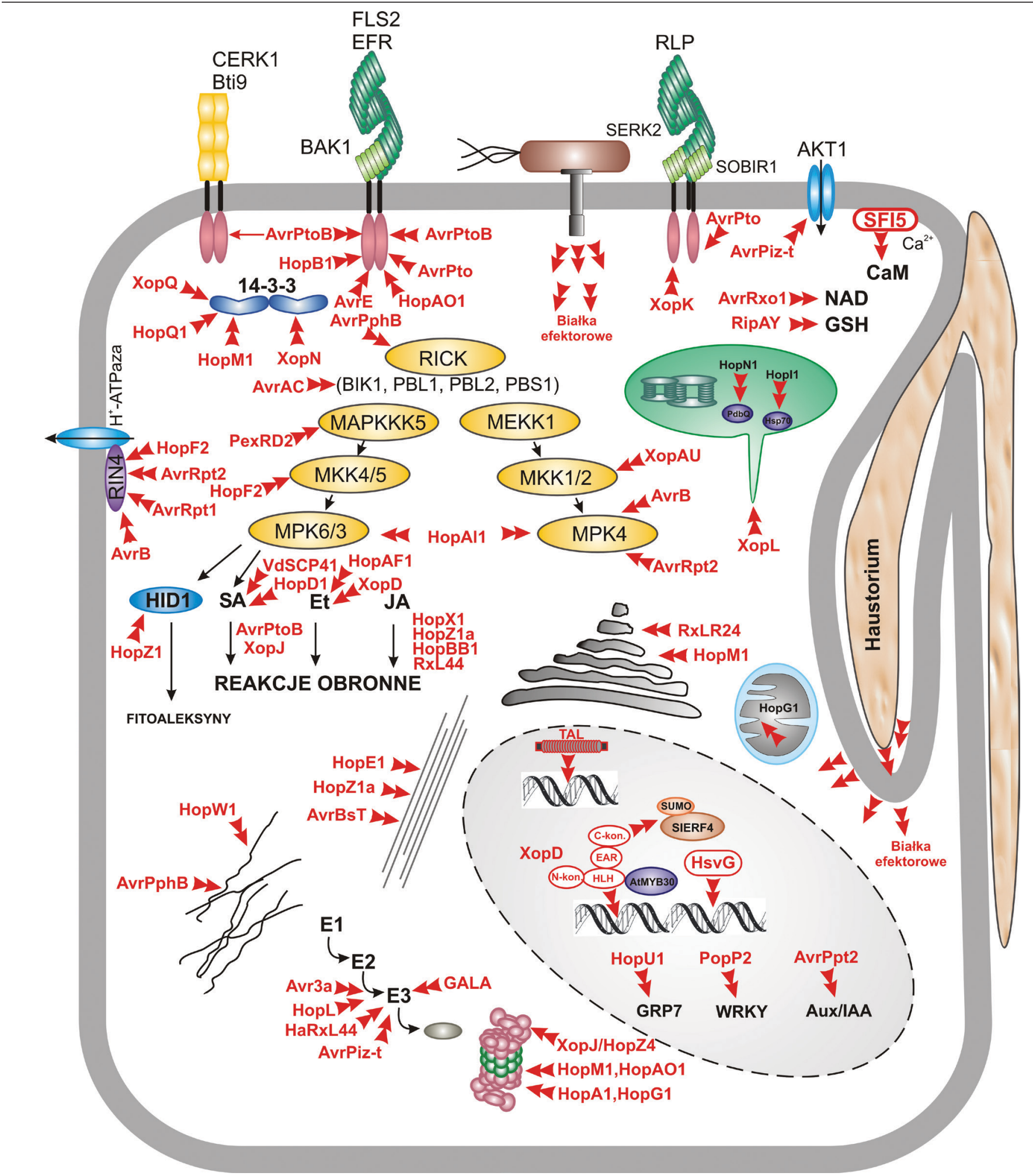

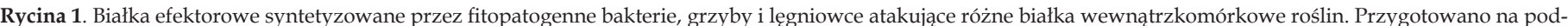
stawie prac $[23,27,30,32,33,36,37,39,41,45,46,57,59,61,70,74]$. 
że AvrPto oddziałuje również z kinazą białkową SOBIR1 rzodkiewnika i pomidora, która jako białko adaptorowe współdziała z wieloma białkami receptorowymi typu RLP tworzącymi kompleksy receptorowe SERK/RLP/ SOBIR1 wiążące niektóre cząsteczki MAMP/PAMP $[1,48]$. Błonowe kinazy receptorowe atakuje też białko efektorowe AvrPtoB z P. syringae, które zawiera trzy różne domeny. Położona w części C-końcowej AvrPtoB domena ligazy ubikwitynowej E3 ulega fosforylacji na reszcie seryny 258, co prowadzi do jej aktywacji i umożliwia ubikwitylację AtFLS2 oraz kinazy receptorowej AtCERK1 pośredniczącej w wiązaniu chityny i peptydoglikanów $[1,23,30,32,33]$. W innych doświadczeniach wykazano, że domena położona w części N-końcowej AvrPtoB blokuje aktywność kinazy Bti9 pomidora, która jest ortologiem kinazy AtCERK1, zaś domena środkowa AvrPtoB hamuje kinazę białkową BAK1 $[23,30]$. Kinaza BAK1/SERK3 należy do rodziny kinaz SERK kodowanych w rzodkiewniku przez pięć genów (SERK1-SERK5). BAK1 funkcjonuje jako kinaza koreceptorowa współtworząca z wieloma błonowymi kinazami białkowymi typu RLK kompleksy receptorowe wiążące cząsteczki MAMP/PAMP, ale także brazinosterodidy, czy peptydy sygnałowe [1]. Kinaza BAK1 jest celem ataku dla jeszcze innego białka efektorowego $P$. syringae, a mianowicie HopB1 z aktywnością proteazy serynowej [49]. W rzodkiewniku HopB1 oddziałuje $\mathrm{z}$ kinazą AtFLS2, ale w obecności flageliny powodującej formowanie kompleksu receptorowego BAK1/flg22/ FLS2-HopB1, białko HopB1 trawi enzymatyczne kinaze BAK1 w obrębie pętli P. Niedawno zidentyfikowano jeszcze białko efektorowe XopK z aktywnością ligazy ubikwitynowej E3 syntetyzowane przez Xanthomonas oryzae, które w ryżu modyfikuje kinazę białkową OsSERK2 [50].

Białko efektorowe HopAO1 z P. syringae z aktywnością fosfatazy tyrozynowej oddziałuje $\mathrm{z}$ domeną kinazową kinazy receptorowej EFR wiążącej N-końcowy odcinek bakteryjnego czynnika elongacyjnego EF-Tu (elf18) i defosforyluje resztę tyrozyny 836, zaburzając w ten sposób funkcjonowanie kompleksu receptorowego BAK1/elf18/ EFR. Ponadto, okazało się, że HopAO1 oddziałuje także z domeną kinazową FLS2 i blokuje szlak sygnałowy aktywowany przez flagelinę $[30,32]$.

Supresja odporności typu PTI odbywa się również na poziomie transkrypcji i translacji genów kodujących kinazy receptorowe FLS2 i EFR. Białko efektorowe HopU1 $\mathrm{z} P$. syringae $\mathrm{z}$ aktywnością mono-ADP-rybozylotransferazy modyfikuje w rzodkiewniku białka wiążące RNA, szczególnie białko GRP7 (ang. Glycine-rich RNA-binding Protein7). GRP7 oddziałuje z transkryptami mRNA kodującymi kinazy receptorowe FLS2 i EFR, ale ADP-rybozylacja reszty argininy 49 w GRP7 uniemożliwia wiązanie transkryptów FLS2 i EFR, hamując w ten sposób translację i obniżając poziom kinaz receptorowych FLS2 i EFR w błonie [30-32]. Ekspresja genu FLS2 w rzodkiewniku blokowana jest również przez białko efektorowe HopQ1 z P. syringae. Mechanizm hamowania ekspresji nie jest do końca jasny, ale wyniki niektórych doświadczeń sugerują, że HopQ1 aktywuje syntezę cytokininy, co ma prowadzić do hamowania ekspresji FLS2 [23,32,42].
Białkami docelowymi atakowanymi przez szereg białek efektorowych są również cytoplazmatyczne kinazy białkowe typu RLCK, które w szlakach sygnałowych są pierwszymi białkami substratowymi fosforylowanymi przez kinazy receptorowe PRR (Ryc. 1) [1]. Ustalono, że białko efektorowe AvrPphB z P. syringae pv. phaseolicola jest preproteazą cysteinową, która wprowadzona do komórek rzodkiewnika ulega aktywacji autokatalicznej oraz mirystylacji i jako zakotwiczona w błonie plazmatycznej proteaza trawi powiązaną z błoną plazmatyczną kinazę PBS1 i podobne do niej kinazy BIK1, PBL1, PBL2 oraz kinazę RIPK [23,30,32,36]. Aktywność kinaz BIK1, PBL2 i RIPK blokuje również białko efektorowe AvrAC/XopAC z X. campestris pv. campestris, które posiada aktywność urydynylotransferazy przenoszącej resztę urydyno 5'-monofosforanu z UTP na reszty seryny-236 i treoniny-237 położone $\mathrm{w}$ domenie kinazowej BIK1 [31].

Aplikacja na roślinę cząsteczki MAMP/PAMP aktywuje szereg tzw. szybkich odpowiedzi, w tym $\mathrm{m}$. in.: obserwowany już po 30-120 s wzrost stężenia $\mathrm{Ca}^{2+} \mathrm{w}$ cytoplazmie, alkalizację środowiska zewnątrzkomórkowego, depolaryzację błony i produkcję ROS [1]. W roślinach, białkami sensorowymi wiążącymi $\mathrm{Ca}^{2+}$ są: kalmodulina (CaM), białka podobne do kalmoduliny (CML), kinazy białkowe zależne od $\mathrm{Ca}^{+}(\mathrm{CPK})$ i białka podobne do kalcyneuryny $\mathrm{B}$ (CBL) aktywujące kinazy białkowe (CIPK). W ostatnim czasie poznano białko efektorowe SFI5 (ang. Suppressor of Flg22-induced Immune response5) z motywem RXLR syntetyzowane przez lęgniowca Phytophthora infestans, które w komórkach pomidora w obecności $\mathrm{Ca}^{2+}$ wiąże CaM i CML. SFI5 jest zbudowanym z 241 reszt aminokwasowych białkiem, które w części C-końcowej ma składający się z 18 reszt aminokwasowych motyw oddziałujący z błoną plazmatyczną i pośredniczący w wiązaniu CaM. Związanie kalmoduliny powoduje oddysocjowanie SFI5 od błony, co prowadzi do hamowania reakcji odpornościowych typu PTI [51]. W tym samym czasie w innej pracowni poznano białko efektorowe AvrPiz-t syntetyzowane przez grzyba Magnaporthe oryzae, które wprowadzone do komórek ryżu blokuje kanał potasowy (OsAKT1) zlokalizowany w błonie plazmatycznej i transportujący $\mathrm{K}^{+}$do cytoplazmy [52]. Wykazano, że OsAKT1 jest aktywowany przez cytoplazmatyczną kinazę białkową OsCIPK23 aktywowaną przez białko OsCBL1 wiążące $\mathrm{Ca}^{2+}$. Oddziaływanie AvrPiz-t z kanałem OsAKT1 przeciwdziała jego fosforylacji przez OsCIPK23, co w efekcie powoduje hamowanie transportu $\mathrm{K}^{+}$i tłumienie reakcji odpornościowych [52].

Po około 2-3 min. od aplikacji cząsteczki MAMP/PAMP $\mathrm{W}$ apoplaście rośnie produkcja anionorodników ponadtlenkowych przekształcanych $\mathrm{w}$ nadtlenek wodoru i stymulowana jest produkcja $\mathrm{H}_{2} \mathrm{O}_{2}$ przez zlokalizowane w ścianie komórkowej peroksydazy klasy III [1,53]. Nadtlenek wodoru hamuje namnażanie fitopatogena, ale pełni także funkcję cząsteczki sygnałowej, dlatego enzymy związane z produkcją i regulacją ROS stały się celem ataku dla szeregu białek efektorowych. Peroksydaza POX12 zlokalizowana w ścianie komórkowej kukurydzy jest blokowana przez białko PEP1 (ang. Protein Essentials during Penetration1) syntetyzowane przez Ustilago maydis i U. hordei, grzyby wywołujące u 
roślin z rodzaju wiechlinowatych głownię guzowatą $[3,53]$. Produkcję ROS hamuje również białko efektorowe AVR-Pii z Magnaporthe oryzae, które w ryżu oddziałuje z enzymem „jabłczanowym” utleniającym i dekarboksylującym kwas jabłkowy. Redukowany w tej reakcji NADP jest m. in. donorem elektronów przekazywanych przez błonową oksydazę NADPH na tlen, który jest redukowany do anionorodnika ponadtlenkowego [53]. Koenzym NAD jest celem ataku dla białka efektorowego AvrRxo1 z X. oryzae pv. oryzicola z aktywnością kinazy nukleotydowej przenoszącej resztę fosforanową z ATP na hydroksyl położony przy węglu 3 rybozy w NAD [54]. Produktami tej reakcji są dwa nowe koenzymy, a mianowicie 3'-NADP i 3'-NAADP, które przypuszczalnie blokują reakcje zależne od $2^{\prime}-\mathrm{NAD}(\mathrm{H})$ i $2^{\prime}-\mathrm{NADP}(\mathrm{H})$. Bakteria Ralstonia solanacearum syntetyzuje białko efektorowe RipAK, które w liściach tytoniu migruje do peroksysomów, gdzie hamuje aktywność katalazy, powodując hamowanie reakcji typu HR we wczesnej fazie infekcji [55]. Innym efektorem syntetyzowanym przez $R$. solanacearum jest białko RipAY z aktywnością Y-L-glutamylo cyklotransferazy (GGCT) metabolizujaccej glutation (GSH) [56]. RipAY przekształca resztę glutaminianu w GSH w 5-oksoprolinę (kwas piroglutaminowy) oraz odszczepia dipeptyd (cysteinylo-glicynę), wpływając w ten sposób na równowagę oksydacyjno-redukcyjną komórki. Kofaktorem $\mathrm{w}$ tej reakcji jest zlokalizowana w cytoplazmie komórek roślinnych tioredoksyna TRX typu h.

Fosforylowane przez kompleksy receptorowe kinazy białkowe RLCK aktywują kaskady kinaz MAP, w rzodkiewniku kaskady MAPKKK5>MKK4/5>MPK3/6 i MEKK1>MKK1/2>MPK4 (Ryc. 1) [1]. Kinazy białkowe współtworzące obie kaskady kinaz MAP są celem ataku dla szeregu białek efektorowych. Kinazy MPK3 i MPK6, a także MPK4 blokuje w rzodkiewniku białko HopAl1 z P. syringae pv. tomato z aktywnością liazy fosfotreoninowej, które powoduje odszczepienie $\mathrm{z}$ fosfotreoniny reszty $-\mathrm{C}-\mathrm{OPO}_{3}{ }^{2-}$, nie zaś, jak w przypadku fosfohydrolaz, hydrolizę wiązania fosfoestrowego. Efektem działania HopAl1 jest supresja szeregu odpowiedzi na aplikację flg22 [23,30,32]. Aktywację kinaz MPK3/6 blokuje również białko HopF2 z P. syringae z aktywnością mono-ADP-rybozylotransferazy, które w kinazie MKK5, a przypuszczalnie także w innych kinazach MKK, modyfikuje resztę argininy [30,32]. Białko efektorowe AvrRpt2 z P. syringae z aktywnością proteazy cysteinowej oraz podobne do niego białka syntetyzowane przez inne bakterie patogenne, blokują w rzodkiewniku fosforylację MPK4 i MPK11, co w efekcie prowadzi do hamowania szeregu reakcji odpornościowych. Na razie nie jest znany mechanizm blokowania MPK4/11, gdyż nie potwierdzono przypuszczenia, że AvrRpt2 degraduje proteolitycznie kinazy MPK4/11 lub kinazy położone w kaskadzie powyżej kinaz MAP [57]. Białko efektorowe AvrB z P. syringae aktywuje fosforylację i aktywację kinazy MPK4, która współtworzy kompleks z kinazą MKS1 i białkami RAR1, Hsp90 i RIN4 [30,32]. Białko efektorowe PexRD2 z motywem RXLR lęgniowca $P$. infestans wprowadzone do komórek ziemniaka oddziałuje $z$ domeną kinazową MAPKKK zaburzając reakcje odpornościowe zależne od kaskady kinaz MAP [58]. W pomidorze i pieprzu białko efektorowe XopAU syntetyzowane przez Xanthomonas euvesicatoria z aktywnością kinazy białkowej fosforyluje kinazę MKK2 ingerując w ten sposób w funkcjonowanie kaskady, co sprzyja kolonizacji pieprzu [59].

W regulacji aktywności kinaz białkowych oraz białek współtworzących szlaki sygnałowe biorą udział fosfatazy białkowe [1]. Heterotrimeryczna fosfataza białkowa PP2A kukurydzy i rzodkiewnika okazała się być celem ataku białek efektorowych z rodziny AvrE syntetyzowanych przez bakterie z kilku rodzajów [60]. Białka WtsE z Pantoea stewartii i AvrE1 z Pseudomonas syringae pv. tomato oddziałują z podjednostką regulatorową B w PP2A, która w rzodkiewniku jest kodowana przez 17 genów. Podjednostka B określa swoistość substratową oraz lokalizację subkomórkową enzymu. Okazało się, że białko AvrE1 wprowadzone do rzodkiewnika hamuje odkładanie kalozy i promuje namnażanie bakterii. Wyniki wcześniejszych badań wykazały, że PP2A uczestniczy w regulacji reakcji odpornościowych, gdyż defosforyluje kinazę BAK1, a także defosforyluje, a przez to destabilizuje enzym ACS odpowiedzialny za syntezę etylenu [60].

Kinazy MAP fosforylują czynniki transkrypcyjne i białka regulujące transkrypcję genów, w tym $\mathrm{m}$. in. genów kodujących enzymy funkcjonujące w biosyntezie fitohormonów oraz fitoaleksyn [1]. W soi ważną fitoaleksyną jest gliceolina, której prekursorem jest daidzeina. Białko efektorowe HopZ1 z P. syringae z aktywnością proteazy/acetylotransferazy trawi proteolitycznie dehydrataze 2-hydroksyizoflawanonową (GmHID1), enzym szlaku biosyntezy izoflawonoidów, zakłócając tym samym syntezę daidzeiny [33].

W wielu szlakach sygnałowych, w tym również w szlakach aktywujących reakcje odpornościowe, ważna rolę odgrywają białka z rodziny 14-3-3 kodowane w rzodkiewniku przez 13 (GRF1 do 13), a w pomidorze przez 12 genów (TFT1 do 12) [61]. Białka 14-3-3 funkcjonują jako fosfosensory oddziałujące $\mathrm{z}$ resztami fosforanowymi różnych białek, wpływając w ten sposób na ich funkcjonowanie. Na przykład, wykazano, że w rzodkiewniku izoformy 14-3-3 oddziałują z kinazami BAK1, CPK1 i czynnikami transkrypcyjnymi WRKY, w kukurydzy z H+-ATPazą, w tytoniu z oksydazą NADPH, w pomidorze z kinazami MAPKKK i MKK2 [61]. Wiele izoform białek 14-3-3 jest celem ataku dla szeregu białek efektorowych, na przykład białko efektorowe HopM1 z P. syringae destabilizuje w rzodkiewniku i pomidorze 14-3$3 \kappa$ i TFT1, które pośredniczą w aktywowanej przez MAMP/ PAMP produkcji ROS i zamykaniu aparatów szparkowych [61]. W pomidorze białko XopN z X. campestris oddziałuje z domeną kinazową nietypowej pseudokinazy białkowej TARK1 oraz z TFT1, funkcjonujących jako pozytywne regulatory PTI. Utworzenie nieaktywnego kompleksu TARK1/ XopN/TFT1 sprzyja supresji reakcji odpornościowych [61]. Białko efektorowe XopQ z X. euvesicatoria oddziałuje z kilkoma białkami TFT pomidora, ale najsilniej z TFT4 funkcjonującym w odporności typu ETI [61]. Podobnie, w pomidorze i tytoniu białko HopQ1 z P. syringae oddziałuje $\mathrm{z}$ szeregiem białek 14-3-3 [61].

Ważnym białkiem regulatorowym wpływającym na reakcje odpornościowe typu PTI i ETI jest zakotwiczone w błonie komórkowej 224-aminokwasowe białko RIN4 (ang. RPM1-Interacting Protein4) zawierające w części N- i C-koń- 
cowej domenę NOI (ang. NO3-induced), a na C-końcu motyw kotwiczący białko w błonie [30,33,62,63]. W poszukiwaniach roli tego białka udało się na razie zidentyfikować kilka białek oddziałujących z RIN4, w tym m. in.: dwie $\mathrm{H}^{+-}$ -ATPazy (AHA1 i AHA2), AAA +-ATPazę (GCN4), kinazy RIPK i MPK4, białko EXO70B1 [30,62]. Białko RIN4 jest obecnie traktowane jako "platforma regulacyjna”, , która ulegając fosforylacji na kilku resztach seryny i treoniny, funkcjonuje jako przełącznik pomiędzy reakcjami typu PTI i ETI [63]. Białko RIN4 jest celem ataku dla co najmniej czterech białek efektorowych z P. syringae, a mianowicie: AvrRpt2, HopF2, AvrB i AvrRpm1. Białko AvrRpt2 rozcina proteolitycznie RIN4 w obrębie domen NOI, co prowadzi do tłumienia reakcji typu PTI. Trawienie RIN4 przez AvrRpt2 jest hamowane przez HopF2, które modyfikuje RIN4 poprzez jego ADP-rybozylację. Białka efektorowe AvrB i AvrRpm1 oddziałują z kinazą cytoplazmatyczną RIPK i kilkoma innymi kinazami z tej rodziny, aktywując w ten sposób fosforylację RIN4 [30,33,63].

\section{DEZORGANIZOWANIE PROCESÓW POWIĄZANYCH BEZPOŚREDNIO LUB POŚREDNIO Z REAKCJAMI ODPORNOŚCIOWYMI}

Fitopatogeny biotroficzne i hemibiotroficzne wykształciły w toku ewolucji w wyniku presji selekcyjnej taki zestaw białek efektorowych, które sprzyjają infekowaniu i zasiedleniu rośliny, ale nie zaburzają procesów biochemicznych na tyle, by zainfekowana komórka nie mogła przeżyć. W kilku następnych podrozdziałach przedstawiono skrótowo poznane białka efektorowe, które ingerują w niektóre procesy komórkowe i osłabiają reakcje odpornościowe (Ryc. 1), ale nadal umożliwiają czerpanie przez fitopatogeny substancji pokarmowych z żywych komórek, chociaż w przypadku hemibiotrofów dzieje się tak, do czasu przejścia w fazę nekrotroficzną.

\section{ZABURZANIE UBIKWITYLACJI I DEGRADACJI BIAEEK W PROTEASOMACH}

$W$ poprzednich podrozdziałach zwracano uwage na białko AvrPtoB z P. syrinage z aktywnością ligazy ubikwitynowej E3 ubikwitynylujące szereg błonowych kinaz białkowych $[30,37,38]$. Ligazą ubikwitynową typu E3 jest również XopK z X. oryzae pv. oryzae modyfikujące i kierujące do degradacji kinazę białkową OsSERK2 [50], a także białko efektorowe XopL z X. campestris pv. vesicatoria. Okazało się, że odcinek C-końcowy w XopL odpowiedzialny za aktywność ligazową nie zawiera zachowawczej reszty cysteiny i nie jest podobny do żadnej z poznanych dotychczas ligaz E3 [37,38].

Oprócz ligaz ubikwitynowych wprowadzanych do rośliny przez fitopatogeny, szereg innych białek efektorowych atakuje białka, które są funkcjonalnie powiązane $\mathrm{z}$ układami ubikwitylacji i degradacji białek w proteasomach (Ryc. 1). Białko AvrPiz-t z grzyba Magnaporthe oryzae oddziałuje z ligazą E3 APIP6 i promuje jej degradację, natomiast białko Avr3a lęgniowca $P$. infestans w ziemniaku stabilizuje ligazę ubikwitynową E3 (CMPG1) typu U-box, która jest normalnie degradowana w proteasomach [37]. Białko efektorowe HaRxL44 syntetyzowane przez Hyaloperonospora arabidopsis oddziałuje z ligazą E3 i białkiem 19a kompleksu Mediato- ra, kierując go degradacji proteasomalnej [36,37]. Ralstonia solanacearum wywołująca u ziemniaka chorobę określaną jako śluzak, syntetyzuje białko GALA z motywem GAxALA zawierające domenę kasety F występującej w białkach współtworzących kompleksy ligaz ubikwitynowych SCF rozpoznających białka substratowe przeznaczone do ubikwitylacji. Przypuszcza się, że GALA konkuruje z białkami F współtworzącymi kompleksy ligaz ubikwitynowych SCF $[30,37]$. Białko efektorowe HopM1 z P. syringae pełni przypuszczalnie funkcję białka adaptorowego, które umożliwia kierowanie białka MIN7 (ARF-GEF) do ubikwitylacji [30,37]. Białko AvrRpt2 z P. syringae z aktywnością proteazy cysteinowej wpływa na degradację proteolityczną białek represorowych AUX/IAA ubikwitynylowanych przez kompleks ligazy SCF ${ }^{\mathrm{TIR} 1}$ pełniacy funkcję receptora auksyn $[42,43]$. Białko efektorowe XopD z X. campestris pv. vesicatoria w części C-końcowej zawiera domenę proteazy odszczepiającej białko SUMO od białka substratowego, np. od czynnika transkrypcyjnego ERF4 [37,38,42,43]. Desumoylacja ERF4 prowadzi do jego degradacji, czego efektem jest hamowanie syntezy etylenu i wzrost podatności rośliny na infekcję.

Poznano też szereg białek efektorowych pochodzenia bakteryjnego, których aktywność jest nakierowana na hamowanie aktywności proteasomów. Białko XopJ syntetyzowane przez X. campestris pv. vesicatoria oraz jego homolog HopZ4 z P. syringae pv. lachrymans z aktywnością proteazy cysteinowej/acetylotransferazy trawią $\mathrm{w}$ roślinie białko RPT6 budujące podjednostkę 19S proteasomu [30,37,38]. Obydwa białka efektorowe kotwiczą w błonie plazmatycznej i dlatego się przypuszcza, że w tym przedziale subkomórkowym hamowaniu podlega aktywność pewnej puli proteasomów. W ostatnim czasie ujawniono, że obok XopJ i HopZ4 aktywność proteasomów hamuje także szereg innych białek efektorowych (HopM1, HopAO1, HopA1, HopG1) syntetyzowanych przez P. syringae pv. tomato [64].

\section{ZAKŁÓCANIE TRANSPORTU PECCHERZYKOWEGO}

Jak już wcześniej wspomniano białko efektorowe HopM1 z P. syringae oddziałuje z jednym z białek GEF (AtMIN7) współdziałającym z małymi białkami $\mathrm{G}$ z podrodziny ARF funkcjonującymi w transporcie pęcherzykowym. Białka GEF, w tym także AtMIN7, pośredniczy w wymianie związanego z ARF GDP na GTP, powodując aktywacje małego białka G. Wyniki doświadczeń pokazują, że wprowadzone do rzodkiewnika HopM1 pełni przypuszczalnie funkcję białka adaptorowego, które kieruje AtMIN7 do ubikwitylacji $[30,32,36,39]$. W ostatnim czasie odkryto, że również białko efektorowe RxLR24 lęgniowca Phytophthora brassicae oraz jego homolog z P. infestans wprowadzone do rzodkiewnika i ziemniaka oddziałują z szeregiem małych białek $G$ z rodziny RAB z podrodziny A (RABA1a, 2a, 4a) funkcjonujących $\mathrm{w}$ transporcie egzocytarnym $\mathrm{z}$ siateczki trans-Golgiego do błony plazmatycznej [65]. Inaktywacja białek RAB powoduje hamowania eksportu, np. białek antybakteryjnych PR-1 i PDF1.2, które w tym wypadku pozostają w siateczce sródplazmatycznej. W tytoniu (N. benthamiana) białko efektorowe AVR3a z Phytophthora infestans oddziałuje z białkiem DRP2 (ang. Dynamin-Related protein2), które jest GTPazą funkcjonującą w endocytozie. W ten sposób AVR3a hamuje 
endocytozę kinazy receptorowej AtFLS2 [36,39]. Wcześniej wykazano, że kinaza AtBAK1 fosforyluje ligazy ubikwitynowe typu U-box (PUB12 i PUB13), które ubikwitynylują kinazę AtFLS2. Wyznakowana w ten sposób kinaza AtFLS2 ulega endocytozie zależnej od klatryny i jest kierowana do wakuoli litycznych, gdzie ulega degradacji proteolitycznej. W ten sposób dochodzi do czasowego odwrażliwienia układu odpornościowego na aktywację przez flagelinę [1].

Wyniki badań z ostatnich lat pokazują, że celem ataku białek efektorowych są również niektóre podjednostki kompleksu egzocysty funkcjonującego w kierowaniu pęcherzyków egzocytarnych do określonego miejsca w błonie plazmatycznej. Białko efektorowe AVR1 z Phytophthora infestans oddziałuje w ziemniaku z białkiem Sec5, zaś białko efektorowe AVR-Pii syntetyzowane przez Magnaporthe oryzae oddziałuje w ryżu z białkami Exo70F2 i-F3 [35,36,66].

\section{INGEROWANIE W PROCESY \\ REORGANIZACJI CYTOSZKIELETU}

Wyniki szeregu dotychczasowych badań pokazują, że cytoszkielet pełni w reakcjach odpornościowych ważne funkcje. Potwierdzają to również badania białek efektorowych, których celem ataku są filamenty aktynowe i mikrotubule (Ryc. 1) [39]. Białko HopW1 z P. syringae pv. maculicola w komórkach rzodkiewnika i tytoniu powoduje demontaż sieci filamentów aktynowych. Rozpad cytoszkieletu aktynowego hamuje endocytozę i zakłóca transport pęcherzykowy pomiędzy wczesnymi a późnymi endosomami oraz wakuolą [30,39]. Cytoszkielet aktynowy destabilizuje także białko HopG1 z P. syringae pv tomato, które w komórkach rzodkiewnika wnika do mitochondriów, gdzie oddziałuje z kinezyną pośredniczącą w sieciowaniu filamentów aktynowych z mikrotubulami. Oddziaływanie HopG1 z kinezyną powoduje łączenie się filamentów w wiązki aktynowe, co sprzyja wzrostowi podatności rzodkiewnika na infekcję [23,30,39]. Podatność na infekcję rośnie również po wprowadzeniu do komórek rzodkiewnika AvrPphB z P. syringae, które oddziałuje z czynnikiem depolimeryzacji aktyny AtADF4 [39].

Odporność rośliny tłumią również białka efektorowe, których celem ataku są mikrotubule. Białko HopE1, syntetyzowane przez $P$. syringae pv tomato, oddziałuje z kalmoduliną i białkiem MAP65 (ang. Microtubule-Associated Protein65) funkcjonującym w sieciowaniu przeciwbiegnących mikrotubul. HopE1 oddziałuje najpierw z kalmoduliną, a następnie $\mathrm{w}$ formie heterodimeru wiąże MAP65. Oddysocjowanie MAP65 od mikrotubul powoduje hamowanie sekrecji białek, w tym także białek antybakteryjnych PR [30,39]. Białko HopZ1a z P. syringae w obecności kwasu fitynowego ulega najpierw autoaktywacji poprzez acetylację reszty lizyny, a następnie, jako aktywna acetylotransferaza przenosi reszty octanowe $\mathrm{z}$ acetylo-CoA na tubulinę. Acetylacja tubuliny prowadzi do drastycznych zmian w sieci mikrotubul, które prowadzą do upośledzenia $\mathrm{w}$ transporcie pęcherzykowym [30,39]. Acetylotransferazą jest również białko AvrBsT z $X$. campestris pv. vesicatoria, które powoduje zakłócenia $\mathrm{w}$ formowaniu sieci mikrotubul. W tym wypadku AvrBsT modyfikuje w rzodkiewniku białko ACIP1 (ang. Acetylated Interacting Protein1) oddziałujące z tubuliną, co staje się przyczyną zmiany lokalizacji ACIP1 i tworzenia agregatów białkowych [30,39].

\section{ZABURZANIE PROCESÓW ZACHODZACYCH W CHLOROPLASTACH I MITOCHONDRIACH}

W badaniach prowadzonych w ostatnich latach uwaga wielu badaczy skupia się na chloroplastach, zwłaszcza na procesach zachodzących na świetle, które wpływają na reakcje odpornościowe. Na pierwszym miejscu należy tu wymienić produkcję przez PSII tlenu singletowego ${ }^{1} \mathrm{O}_{2}$ oraz anionorodników ponadtlenkowych przez PSI, ale także, potwierdzany w wielu doświadczeniach, transport $\mathrm{Ca}^{2+} \mathrm{z}$ cytoplazmy do chloroplastów $[39,40]$. Okazało się, że powyższe zmiany mają swój udział w aktywowanych przez flagelinę rozległych zmianach w ekspresji genów [40]. Interesujące wyniki uzyskano także w analizach ekspresji genów jądrowych kodujących białka funkcjonujące w chloroplastach NECG (ang. Nuclear Encoded Chloroplast-targeted Genes) $[39,67]$ Okazało się, że cząsteczki typu MAMP/PAMP pochodzące z P. syringae pv. tomato już po 2 godz. od infekcji liści rzodkiewnika, aktywują ekspresję ponad 350 i hamują ekspresję około 500 genów NECG, spośród 3678 analizowanych genów. Po 4 godz. od czasu infekcji, liczba genów NECG, których ekspresja jest hamowana wzrasta do ponad 1100 [67]. Podobnie szybko zmienia się ekspresja genów NECG po wprowadzeniu do komórek białek efektorowych pochodzących z P. syringae [67]. Przeprowadzona przez autorów analiza sekwencji aminokwasowej 48 białek efektorowych bakterii z rodzaju Pseudomonas sugeruje, że aż 21 białek może wnikać do chloroplastów, a spośród 19 analizowanych białek z Xanthomonas pv. campestris, 10 białek przypuszczalnie migruje do chloroplastów [67]. Jednakże w dotychczasowych badaniach zidentyfikowano zaledwie kilka białek efektorowych, które bezpośrednio ingerują w procesy zachodzące $\mathrm{w}$ chloroplastach. Przed ponad 10 laty poznano HopI1 z P. syringae, które w chloroplastach rzodkiewnika oddziałuje $\mathrm{z}$ białkiem szoku termicznego Hsp70, dezorganizuje ultrastrukturę tylakoidów i wyraźnie hamuje syntezę kwasu salicylowego [33,39]. Inne białko efektorowe HopN1 z P. syringae z aktywnością proteazy cysteinowej $\mathrm{w}$ liściach pomidora degraduje białko PsbQ współtworzące kompleks fotosystemu II, co powoduje $\mathrm{m}$. in. hamowanie produkcji ROS [33,39]. Wykazano też, że dwa inne białka z P. syringae, a mianowicie HopK1 i AvrRPS4 po wprowadzeniu do komórek rzodkiewnika ulegają proteolitycznemu rozcięciu, a następnie wnikają do chloroplastów [39].

W ostatnim czasie zwrócono uwagę na stromule, jako te struktury tubularne, które umożliwiają komunikację chloroplastów z innymi organellami, w tym także z jądrem. Okazało się, że stromule odgrywają ważną rolę w reakcjach odpornościowych, pośrednicząc przypuszczalnie $\mathrm{w}$ transporcie $\mathrm{H}_{2} \mathrm{O}_{2} \mathrm{i}$ kwasu salicylowego $\mathrm{z}$ chloroplastów do jądra [68]. W komórkach epidermalnych tytoniu funkcjonowanie stromuli zaburza białko XopL z Xanthomonas campestris pv. vesicatoria $\mathrm{z}$ aktywnością ligazy ubikwitynowej E3. Wykazano, że XopL oddziałuje z mikrotubulami, co powoduje zanikanie stromuli i ogranicza możliwość przemieszczania się chloroplastów w kierunku jądra [69]. 
W dotychczasowych badaniach zidentyfikowano tylko jedno białko efektorowe, które wnika do mitochondriów. Jest nim białko HopG1 z P. syringae, które w części N-końcowej ma sekwencję kierującą do mitochondriów. Jak już wcześniej wspomniano HopG1 w rzodkiewniku, tytoniu i pomidorze destabilizuje $\mathrm{w}$ mitochondriach cytoszkielet aktynowy poprzez oddziaływanie z kinezyną. Efektem działania HopG1 jest łączenie się filamentów w wiązki aktynowe, co prowadzi do szeregu defektów rozwojowych, które przypuszczalnie mają związek $\mathrm{z}$ hamowaniem oddychania $[23,30,39]$.

\section{ZAKŁÓCANIE BIOSYNTEZY FITOHORMONÓW I INGEROWANIE W HORMONALNE SZLAKI SYGNAŁOWE}

Zagadnienia dotyczące wpływu białek efektorowych na biosyntezę fitohormonów oraz funkcjonowanie szlaków i sieci sygnałowych aktywowanych przez fitohormony zajmują w badaniach układu odpornościowego jedno z kluczowych miejsc [43]. W obecnym podrozdziale zostaną skrótowo omówione tylko te białka efektorowe, które w różny sposób zaburzają funkcjonowanie hormonów bezpośrednio powiązanych z układem odpornościowym, a więc: kwasu salicylowego (SA), etylenu (ET) i kwasu jasmonowego (JA) (Ryc. 1) [30,41,42]. W kukurydzy, biosyntezę SA hamuje mutaza choryzmianowa (Cmu1) syntetyzowana przez Ustilago maydis, natomiast $\mathrm{w}$ soi izochoryzmataza (PsIsc1) z lęgniowca Phytophthora sojae i (VdIsc1) grzyba Verticillium dalia. W obu przypadkach dochodzi do niepożądanych przemian intermediatów szlaku biosyntezy SA rozpoczynającego się od kwasu choryzmowego [70]. Biosyntezę SA hamuje również wspomniane już białko HopI1 z P. syringae, które w chloroplastach oddziałuje $\mathrm{z}$ białkiem szoku termicznego Hsp70 i dezorganizuje strukturę tylakoidów [39,41]. W rzodkiewniku białko HopD1 z P. syringae pv. tomato oddziałuje z białkiem NTL9 z rodziny czynników transkrypcyjnych NAC z motywem transbłonowym, kotwiczącym w błonie siateczki śródplazmatycznej. Przypuszcza się, że HopD1 zaburza migrację NTL9 do jądra, gdzie aktywuje ekspresję genu ICS1 kodującego kluczowy enzym szlaku biosyntezy SA [30]. W rzodkiewniku i bawełnie biosyntezę SA blokuje białko efektorowe VdSCP41 z grzyba Verticillium dahliae, które oddziałuje z czynnikiem transkrypcyjnym wiążącym kalmodulinę CBP60g i podobnym do niego SARD1 regulujących $\mathrm{m}$. in. ekspresję genu ICS [71]. Szlaki sygnałowe aktywowane przez SA zakłóca wspomniane wcześniej białko AvrPtoB z P. syringae, które w obecności SA ubikwityluje NPR1, jedno z trzech białek receptorowych SA regulujących ekspresję genów aktywowanych przez SA [72]. Białko NPR1 występuje w cytoplazmie w formie homooligomerów, które w obecności SA i tioredoksyny dysocjują do monomerów migrujących do jądra, gdzie oddziałują $\mathrm{z}$ czynnikami transkrypcyjnymi TGA. Okazało się, że poziom NPR1 w jądrze musi podlegać ścisłej regulacji m. in. poprzez degradację $\mathrm{w}$ proteasomach. Wspomniane wcześniej białko XopJ z X. campestris, trawiące proteolitycznie podjednostkę RPT6 proteasomu, hamuje degradację białka NPR1 zakłócając $\mathrm{w}$ ten sposób ekspresję genów aktywowanych przez fitohormon [41,70]. Aktywowaną przez SA ekspresję genów PR1 w rzodkiewniku i soi hamują białka efektorowe
HaRxL62 i HaRxL96 z lęgniowca Hyaloperenospora arabidopsis i PsAvh163 z Phytophthora sojae [70].

Syntezę ET w rzodkiewniku hamuje białko HopAF1 z $P$. syringae, które atakuje nukleozydazy metyltioadenozynowe MTN1 i 2, enzymy cyklu Yanga odpowiedzialnego za odtwarzanie metioniny potrzebnej $\mathrm{w}$ biosyntezie etylenu. Hamowanie przez HopAF1 cyklu Yanga ogranicza aktywowaną przez cząsteczki MAMP/PAMP biosyntezę ET [73]. W pomidorze, syntezę ET hamuje również białko XopD z X. euvesicatoria, które, jak już wcześniej wspomniano, odszczepia od czynnika transkrypcyjnego SlERF4 białko SUMO. Desumoilacja białka SlERF4 kieruje go do degradacji w proteasomach, co powoduje hamowanie syntezy ET [37,38,41].

W dotychczasowych badaniach nie znaleziono białek efektorowych zakłócających syntezę JA, natomiast zidentyfikowano kilka białek, które ingerują w szlaki sygnałowe aktywowane przez ten fitohormon [30,41,74]. Białka HopX1 i HopZ1a z P. syringae degradują białka JAZ (ang. Jasmonate Zim Domain), które funkcjonują jako represory genów aktywowanych przez JA. Białko HopX1 jest proteazą cysteinową trawiącą białka JAZ, natomiast HopZ1 z aktywnością acetylotransferazy/proteazy cysteinowej acetyluje JAZ, co ostatecznie sprzyja ich ubikwitylacji i degradacji proteasomalnej $[30,74]$. Białko HopBB1 z P. syringae oddziałuje z białkiem JAZ3 oraz białkiem represorowym TCP14, со umożliwia tworzenie heterotrimeru TCP14/HopBB1/JAZ3 kierowanego do kompleksu ligazy ubikwitynowej SCFCOI [75]. Białko efektorowe RxL44 z lęgniowca Hyaloperonospora arabidopsis oddziałuje z białkiem MED19a kompleksu Mediatora, kierując go do degradacji w proteasomach, co powoduje wzmocnienie ekspresji genów związanych z JA i ET [74].

W tym miejscu warto podkreślić, że białka efektorowe ingerujące $\mathrm{w}$ funkcjonowanie SA i JA zaburzają także odporność szparkową [36]. Wiadomo, że aktywowane przez cząsteczki typu MAMP/PAMP zamykanie aparatów szparkowych jest jedną z ważniejszych odpowiedzi obronnych przeciwdziałających infekowaniu rośliny [1]. Ruchy aparatu szparkowego reguluje głównie ABA, ale zamykanie szparek aktywuje również SA, podczas gdy JA działa antagonistycznie. Oczywiście, odporność szparkową zaburzają również te białka efektorowe, które blokują receptory PRR, zakłócają funkcjonowanie cytoplazmatycznych kinaz RLCK, enzymów produkujących ROS i kanałów wapniowych, czy kinaz białkowych CPK i CIPK $[30,36,53]$.

\section{ZABURZANIE PROCESÓW TRANSKRYPCJI I TRANSLACJI GENÓW}

Analizy porównawcze ekspresji genów związanych z aktywacją PTI oraz zmian towarzyszących wprowadzeniu do rzodkiewnika białek efektorowych z P. syringae zwróciły uwagę na zaskakująco duży, w obu przypadkach, zakres zmian w ekspresji genów [44]. Aktywacja PTI przez cząsteczki MAMP/PAMP już po 2 godz. od infekcji powoduje przeprogramowanie ekspresji około 1200 genów, z tego ekspresja około 400 genów rośnie, a maleje ekspresja około 800 genów. Supresji ulegają głównie geny związane 
z funkcjonowaniem chloroplastów, natomiast rośnie ekspresja genów związanych z produkcją ROS, fosforylacją białek, modyfikacjami potranslacyjnymi, odpowiedziami na SA, syntezą fitoaleksyn. Zmiany towarzyszące wprowadzeniu do komórek białek efektorowych z P. syringae pojawiają się nieco później i po 6 godz. rośnie ekspresja około 800 genów, a ekspresja około 600 genów maleje. Zmiany w ekspresji dotyczą głównie genów kodujących białka związane $\mathrm{z}$ regulacją transkrypcji i białka uczestniczące $\mathrm{w}$ transporcie czynników transkrypcyjnych do jądra oraz białka funkcjonujące w autofagii, a także genów związanych z syntezą ABA [44]. W poprzednim podrozdziale zwracano już uwage na podobne analizy w ekspresji genów NECG (ang. Nuclear Encoded Chloroplast-targeted Genes) związanych $\mathrm{z}$ funkcjonowaniem chloroplastów. Również te analizy wskazują na równie szybkie i rozległe zmiany związane z aktywacją PTI i dalsze, równie szybkie zmiany towarzyszące wprowadzeniu białek efektorowych z P. syringae [67].

Od jakiegoś czasu, duże zainteresowanie, również ze względów praktycznych, budzą białka efektorowe TAL (ang. Transcription Activator-Like) syntetyzowane przez bakterie z rodzaju Xanthomonas i Ralstonia [45,76]. Białka te w części C-końcowej mają motyw skierowujący do jądra (NLS), za którym jest położona domena kwaśna aktywująca transkrypcję, natomiast w części środkowej występuje domena utworzona z kilkunastu, do kilkudziesięciu 34-aminokwasowych powtórzeń. W każdym takim powtórzeniu w pozycjach 12 i 13 występuje dwuaminokwasowy motyw zmienny RVD (ang Repeat-Variable Diresidues) rozpoznający określoną zasadę w DNA. Białka TAL mogą się wiązać do sekwencji promotorowych różnych genów, ale także, jak się przypuszcza, mogą oddziaływać z polimerazą RNA II i regulatorami negatywnymi polimerazy II $[30,76]$. W pojedynczych doniesieniach wykazano, że w ryżu PthXo1 z X. oryzae pv. oryzae, a także PthXo2, PthXo3, AvrXa7, TalC i Tal5 aktywują ekspresję genów OsSWEET11-15 kodujących białka transportujące cukry z komórki do apoplastu [76]. Inne białko efektorowe AvrBs3 X. spp. aktywuje w pieprzu ekspresję genu UPA20 kodującego czynnik transkrypcyjny odpowiedzialny za regulację genów związanych z hypertrofią, w tym $\mathrm{m}$. in. genu ekspansyny- $\alpha$. Obserwowany $\mathrm{w}$ tym wypadku nadmierny rozrost komórek epidermy prowadzi do pękania warstwy okrywającej, co sprzyja infekcji bakteryjnej. Bakteria $X$. citri syntetyzuje kilka efektorów TAL (PthA, B, C i TalC), które w cytrynie aktywują ekspresję CsLOB1 kodującego czynnik transkrypcyjny odpowiadający za powstawanie powierzchniowej chropowatości sprzyjającej infekcjom [76].

Wspomniane już wcześniej białko efektorowe XopD z X. campestris pv. vesicatoria $\mathrm{w}$ liściach pomidora lokalizowane jest w ciałach jądrowych (foci) [30,46,47]. XopD jest stosunkowo dużym białkiem (760 reszt aminokwasowych) obejmującym cztery różne domeny pełniące odmienne funkcje (Ryc. 1). W części środkowej położona jest domena HLH oddziałująca niespecyficznie z DNA i wiążąca czynnik transkrypcyjny AtMYB30. Leżąca za nią domena EAR oddziałuje z czynnikami transkrypcyjnymi regulującymi ekspresję genów związanych z odpornością i stresem, a w części C-koncowej występuje domena $\mathrm{z}$ aktywnością proteolityczną od- cinającą od białek małe białka SUMO. Czwarta, najmniejsza domena N-końcowa XopD pełni przypuszczalnie funkcję regulacyjną. Oddziaływanie XopD z białkiem AtMYB30 zaburza funkcjonowanie tego ważnego czynnika transkrypcyjnego regulującego ekspresję genów związanych z odpornością, w tym $\mathrm{m}$. in. genów związanych $\mathrm{z}$ metabolizmem długołańcuchowych kwasów tłuszczowych [46]. Aktywność proteolityczną domeny C-końcowej XopD potwierdzono w przypadku wspominanego już wcześniej czynnika transkrypcyjnego SlERF4. Desumoylacja SlERF4 prowadzi do jego degradacji proteolitycznej i hamowania produkcji etylenu [41]. Bakteria Pantoea agglomerans (dawniej Ervinia herbicola) syntetyzuje białko efektorowe HsvG, które w buraku aktywuje ekspresję genu HSVGT kodującego czynnik transkrypcyjny. Białko HsvG w części N- i C-końcowej ma motywy NLS, natomiast w części środkowej domenę HTH (ang. Helix-Turn-Helix) i dwa odcinki R1 i R2 odpowiedzialne za swoistość oddziaływania z DNA [30]. Białko PopP2 $\mathrm{z} R$. solanacearum $\mathrm{z}$ aktywnością acetylotransferazy modyfikuje reszty lizyny $\mathrm{w}$ wielu czynnikach transkrypcyjnych z rodziny WRKY liczącej w rzodkiewniku 74 białek [30]. W poprzednich podrozdziałach zwracano już uwagę na szereg białek efektorowych, które zaburzają funkcjonowanie fitohormonów. W rzodkiewniku białko HopD1 z P. syringae pv. tomato zaburza transport czynnika transkrypcyjnego NTL9 do jądra, hamując w ten sposób ekspresję genu ICS1 kodującego kluczowy enzym szlaku biosyntezy SA [30]. Białka HopX1, HopZ1a i HopBB1 z P. syringae ingerują w szlaki sygnałowe aktywowane przez JA [30,74,75], AvrRpt2 z P. syringae $\mathrm{z}$ aktywnością proteazy cysteinowej trawi białka represorowe AUX/IAA regulujące odpowiedzi na auksyny, a XopD $\mathrm{Xcc804}_{\mathrm{z}} \mathrm{X}$. campestris stabilizuje białka represorowe DELLA zaburzając $\mathrm{w}$ ten sposób aktywację genów regulowanych przez gibereliny (GA) [30,43]. Białko HopM1 oddziałuje z GRF8/MIN10 z rodziny 14-3-3, powodując hamowanie transportu czynnika transkrypcyjnego BZR1 z cytoplazmy do jądra [30]. Białko BZR1 jest kluczowym elementem szlaku sygnałowego aktywowanego przez brazinosteroidy $(\mathrm{Br})[43]$.

W poprzednich podrozdziałach zwracano uwage na białko efektorowe HopU1 z P. syringae pv. tomato DC3000 $\mathrm{z}$ aktywnością mono-ADP-rybozylotransferazy, który w rzodkiewniku modyfikuje białka wiążące RNA, szczególnie białka GRP7 i GRP8 [30]. GRP7 oddziałuje z transkryptami mRNA kodującymi FLS2 i EFR, a także ze składnikami układu translacyjnego, białkami eIF4E i S14. ADP-rybozylowane GRP7 przestaje oddziaływać z transkryptami FLS2 i EFR, co prowadzi do obniżenia poziomu białek receptorowych FLS2 i EFR [30]. Białko efektorowe 30D08 nicienia Heterodera schachtii wprowadzone do komórek rzodkiewnika wnika do jądra, gdzie oddziałuje z białkiem SMU2 (ang. Suppressor of Mec-8 and Unc52 2) funkcjonujaccym jako białko pomocnicze spliceosomu. Białko 30D08 powoduje zmiany w ekspresji 2180 genów, w tym genów związanych z obróbką, transkrypcją i wiązaniem RNA [77]. Białko efektorowe PsAvh23 z Phytophthora sojae zaburza oddziaływanie podjednostki ADA2 z podjednostką katalityczną GCN5 kompleksu acetylotransferazy histonowej. Wiązanie podjednostki ADA2 współtworzącej kompleks acetylotransferazy SAGA zaburza acetylację histonu H3K9 i powoduje deregulację ekspresji genów związanych z odpornością [78]. 


\section{UWAGI KOŃCOWE}

Prezentowane w pracy mechanizmy molekularne wykorzystywane w tłumienia odporności podstawowej i sprzyjające opanowaniu rośliny przez atakujący fitopatogen dotyczą wyłącznie białek efektorowych syntetyzowanych i wprowadzanych do wnętrza komórek infekowanej rośliny .przez fitopatogenne bakterie, grzyby i grzybopodobne lęgniowce. Na podstawie informacji zawartych w pracy można łatwo się zorientować, że większość poznanych pod względem biochemicznym białek efektorowych pochodzi z kilku patogennych szczepów Pseudomonas syringae wywołujących bakteriozy. Są to szczepy: Pst DC3000 powodujący plamistość pomidora, rzodkiewnika i infekujący tytoń (N. benthamiana), Pss-pv. syringae zakażający bez, gruszę i fasolę, Pph-pv. phaseolicoloa wywołujący zarazę fasoli i Pta-pv. tabaci zakażający tytoń [22]. W badaniach laboratoryjnych, szczepem najczęściej wykorzystywanym jest $P$. syringae pv. tomato DC3000 syntetyzujący zestaw 29 białek efektorowych, które pod względem charakterystyki biochemicznej oraz sposobu ingerowania w funkcjonowanie białek docelowych w funkcjonowanie białek docelowych są najlepiej przebadanymi efektorami [23,30,79]. Poszczególne gatunki i patogenne szczepy bakterii z rodzaju Xanthomonas zakażają około 120 roślin jednoliściennych i 270 dwuliściennych, ale w badaniach białek efektorowych wykorzystuje się kilka szczepów, takich jak: Xoo (X. oryzae pv. oryzae), $X a c(X$. axonopolis pv. citri, Xcv (X. campestris pv. vesicatoria) i Xcc (X. campestris pv. campestris), u których poznano w sumie około 20 białek efektorowych [24,30]. Patogenne szczepy Ralstonia solanacearum zakażają ponad 200 roślin, w tym wiele roślin uprawnych, wywołując u roślin psiankowatych chorobę zwaną śluzakiem, np. zgniliznę ziemniaka. $W$ badaniach białek efektorowych przez $R$. solanacearum poznano dotychczas tylko cztery białka (PopP2, GALA, RipAY RipTps), chociaż każdy z patogennych szczepów syntetyzuje zestaw około 60-75 białek [25,30]. Podjęte niedawno analizy białek efektorowych pochodzenia bakteryjnego pod kątem ich lokalizacji subkomórkowej, funkcji biologicznej oraz specyficzności względem białkom docelowym wykazały, że większość, bo prawie 70\% tych białek atakuje dwa lub więcej białek docelowych z tej samej lub z różnych klas [26]. Potwierdzają to również, nieco zaskakujące, wyniki doświadczeń opublikowane w ostatnim czasie [80]. Techniką SLCA (ang. Split Luciferase Complementation Assay) badano w protoplastach pomidora oddziaływania pomiędzy pięcioma białkami efektorowymi z Pst DC3000 (HopAI1, AvrPto, HopA1, HopM1, HopAF1) a 279 kinazami białkowymi pomidora. Na podstawie dotychczasowych badań było wiadomo, że tylko dwa z pięciu badanych białek efektorowych (AvrPto, HopAI1) ingerują w aktywność kinazową atakowanych białek, natomiast pozostałe trzy białka zakłócają funkcjonowanie zupełnie innych białek. HopAF1 zaburza aktywność MTN1 i 2, enzymów funkcjonujących w syntezie etylenu [73], HopM1 atakuje MIN7, GRF8, a HopA1 oddziałuje z białkiem EDS1 funkcjonującym w ETI (Ryc. 1). Wyniki analiz pokazały, że połowa badanych kinaz białkowych oddziałuje z co najmniej jednym białkiem efektorowym, $48 \%$ kinaz oddziałuje $\mathrm{z}$ wiecej niż trzema efektorami, a tylko HopM1 nie oddziałuje z żadną z badanych kinaz białkowych [80]. Kinazy białkowe oddziałujące z efektorami należą do różnych klas (RLK, RLCK, MAPK) i wiele z nich funkcjonuje w odporności typu PTI i ETI, a także w aktywacji programowanej śmierci komórki (PCD) [80].

W odróżnieniu od fitopatogenów bakteryjnych syntetyzujących zestawy kilkudziesieciu białek efektorowych, genomy grzybów i lęgniowców kodują setki takich efektorów [81]. Wiedza na temat białek efektorowych syntetyzowanych przez grzyby była jeszcze niedawno bardzo ograniczona [82]. Pewien postęp nastąpił po tym jak $\mathrm{w}$ Magnaporthe oryzae zidentyfikowano konserwatywną strukturę MAX (ang. Magnaporthe Avrs and ToxB like), która jak się okazało występuje w ośmiu poznanych białkach efektorowych (AVR-Pia, AVR1-CO39, AVR-Pii, AVR-Pik, AvrPiz-t, AVR-Pita, Avr-Pi9 i PWL2) [27,81,83]. W Blumeria graminis pv. hordei zidentyfikowano konserwatywną strukturę RALPH występującą u szeregu poznanych białek $\left(\mathrm{AVR}_{\mathrm{A} 1}, \mathrm{AVR}_{\mathrm{A} 13}\right.$, AvrPm2), a u Melampsora lini poznano sześć białek efektorowych (AvrL567, AvrM, AvrP4, AvrP123, AvrL2 i AvrM14), z występujacym u niektórych białek podobieństwem strukturalnym [81]. W sumie, u dwóch grzybów biotroficznych (Blumeria graminis, Melampsora lini) i trzech hemibiotrofów (Magnaporthe oryzae, Leptosphaeria maculans, Fusarium oxysporum) poznano dotychczas około 20 białek efektorowych [27], a w infekowanych roślinach zidentyfikowano około dziesieciu immunoreceptorów wewnątrzkomórkowych NB-LRR rozpoznających niektóre $\mathrm{z}$ tych białek $[27,84]$.

Zdecydowanie więcej wiemy obecnie na temat liczby oraz funkcji biologicznej białek efektorowych syntetyzowanych przez lęgniowce. Identyfikowanie genów kodujących te białka $\mathrm{w}$ lęgniowcach ułatwia fakt, że wiele $\mathrm{z}$ nich posiada charakterystyczne motywy (RxLR-dEER, Crinkler motif, CHxC, LxLFLAK) [28,81]. Motyw RXLR (Arg-reszta dowolnego aminokwasu-Leu-Arg) występuje za motywem stanowiącym sygnał sekrecyjny, a poprzedza domenę efektorową zlokalizowaną w części C-końcowej. W strukturze krystalicznej tych białek wyodrębniono jeszcze domenę WY (Trp, Tyr) tworzącą charakterystyczną pętlę WY [81,85]. Genomy trzech gatunków hemibiotroficznych Phytophthora, a mianowicie P. infestans, $P$. ramorum i $P$. sojae zawierają odpowiednio 563, 396 i 374 genów kodujących białka z motywem RXLR [28], dlatego w dotychczasowych badaniach te białka stały się przedmiotem największego zainteresowania [28]. Właściwości i funkcję biochemiczną poznano, co najmniej częściowo, w przypadku około 20 białek z motywem RxLR i około 6 białek z rodziny CRN syntetyzowanych przez $P$. infestans, $P$. sojae i biotroficzny Hyaloperonospora arabidopsis, a w roślinach zidentyfikowano szereg immunoreceptorów NB-LRR rozpoznających niektóre z tych białek [27,28]. Początkowo przypuszczano, że motyw RXLR uczestniczy $\mathrm{w}$ transporcie endocytarnym białka z przestrzeni zawartej pomiędzy błoną haustorium a błoną plazmatyczną komórki roślinnej (Ryc. 1), jednakże wyniki najnowszych badań pokazują, że motyw RXLR jest odcinany proteolitycznie w haustorium,tak że do przestrzeni międzybłonowej migruje domena efektorowa $\mathrm{z}$ acetylowaną na N-końcu resztą lizyny [86]. W badaniach poświęconych analizom ekspresji genów kodujących białka RXLR wykazano, że poziom transkryptów rośnie już na bardzo wczesnym etapie infekcji [87]. W doświadczeniach, w których liście ziemniaka infekowano cystami z pięciu różnych szczepów P. infestans, 
a następnie po upływie 12 godz., gdy wewnątrz tkanki liściowej formują się już haustoria [88], izolowano materiał do analiz RNA. Okazało się, że w materiale pobranym do analiz po 12 godz. od infekcji, w pięciu różnych szczepach $P$. infestans zidentyfikowano transkrypty 245 genów RXLR. U każdego badanego szczepu ekspresji ulega 108 genów, 34 geny są transkrybowane u czterech szczepów, 29 u trzech, 30 u dwóch i 44 geny ulegają transkrypcji tylko u jednego szczepu [87]. Wykrywanie białek efektorowych RXLR w komórkach rośliny jest prawie niemożliwe, ze względu na ich bardzo niski poziom, ale umożliwiają to techniki oparte na ekspresji w roślinie konstruktu takiego jak np. GFP-RXLR [89]. Wprowadzenie do N. benthamiana 52 konstruktów GFP-RXLR kodujących różne białka z P. infestans pozwoliło wykazać, że $41 \%$ wyznakowanych białek występuje w cytoplazmie i jądrze, $25 \% \mathrm{w}$ jądrze, $7 \% \mathrm{w}$ cytoplazmie, $18 \%$ migruje do błony plazmatycznej. Ponadto, w doświadczeniach, w których GFP-RXLR wprowadzono do rośliny infekowanej $P$. infestans ujawniono, że szereg białek GFP-RXLR gromadziło się wokół haustoriów [89].

W kontekście prezentowanych tutaj informacji zasadne wydaje sie pytanie o to, dlaczego grzyby i lęgniowce syntetyzują setki białek efektorowych, podczas gdy genomy bakterii kodują tylko dziesiątki takich białek. Biorąc pod uwage prezentowane wyniki wskazujące na niemal masywną ekspresję genów RXLR już we wczesnej fazie infekcji, zagadkowe stają się wyniki pokazujące, że wyłączenie nawet jednego genu, np. AVR $3 a$ w P. infestans staje się przyczyną wyraźnego spadku wirulencji [90]. Analizy białek efektorowych pochodzenia bakteryjnego pod kątem ich specyficzności względem białkom docelowym [26], a także opisane wyżej wyniki najnowszych doświadczeń [80] prowadzą do wniosku, że większość tych białek atakuje w roślinach wiele białek docelowych. Na razie nie wiemy czy białka efektorowe grzybów i lęgniowców funkcjonują w roślinach inaczej, dlatego nie można zakładać, że ich duża liczba świadczy o ich funkcjonalnej redundancji. Pytania o różnice pomiędzy białkami efektorowymi bakterii, a białkami grzybów i lęgniowców stawiane są również w pracy opublikowanej w ubiegłym roku [91], jednakże, zdaniem autorów, proponowane $\mathrm{w}$ niej sugestie wydają się przedwczesne, bowiem wiedza na temat swoistości substratowej, a także funkcji biochemicznej białek pochodzacych z grzybów i legniowców jest jeszcze bardzo ograniczona.

\section{PIŚMIENNICTWO}

1. Hetmann A, Kowalczyk S (2018) Receptory błonowe wiążące cząsteczki typu MAMP/PAMP i DAMP aktywujące pierwszą linię obrony lokalnej układu odpornościowego roślin. Post Biochem 64: 29-45

2. Jones JDG, Dangl JL (2006) The plant immune system. Nature 444: 323329

3. Wang Y, Wang Y (2018) Trick or treat: Microbial pathogens evolved apoplastic effectors modulating plant susceptibility to infection. Mol Plant-Microbe Interact 31: 6-12

4. Hogenhout SA, Van der Hoorn RAL, Terauchi R, Kamoun S (2009) Emerging concepts in effector biology of plant-associated organisms. Mol Plant-Microbe Interact 22: 115-122

5. Dalio RJD, Herlihy J, Oliveira TS, McDowell JM, Machado M (2018) Effector biology in focus: A primer for computational prediction and functional characterization. Mol Plant-Microbe Interact 31: 22-33
6. Galán JE, Lara-Tejero M, Marlovits TC, Wagner S (2014) Bacterial type III secretion systems: specialized nanomachines for protein delivery into target cells. Annu Rev Microbiol 68: 415-438

7. Mach J (2017) Tracking the bacterial type III secretion system: Visualization of effector delivery using split fluorescent proteins. Plant Cell 29: $1547-1548$

8. Lo Presti L, Kahmann R (2017) How filamentous plant pathogen effectors are translocated to host cells. Curr Opin Plant Biol 38: 19-24

9. Hewezi T (2015) Cellular signaling pathways and posttranslational modifications mediated by nematode effector proteins. Plant Physiol 169: 1018-1026

10. Basu S, Varsani S, Louis J (2018) Altering plant defenses: Herbivore-associated molecular patterns and effector arsenal of chewing herbivores. Mol Plant-Microbe Interact 31: 13-21

11. Kaloshian I, Walling LL (2016) Hemipteran and dipteran pests: Effectors and plant host immune regulators. J Integr Plant Biol 58: 350-361

12. Jaouannet M, Rodriguez PA, Thorpe P, Lenoir CJG, MacLeod R, Escudero-Martinez C, Bos JIB (2014) Plant immunity in plant-aphid interactions. Front Plant Sci 5: 663

13. Ling Y, Weilin Z (2016) Genetic and biochemical mechanisms of rice resistance to planthopper. Plant Cell Rep 35: 1559-1572

14. Muthamilarasan M, Prasad M (2013) Plant innate immunity: An updated insight into defense mechanism. J Biosci 38: 1-17

15. Bentham A, Burdett H, Anderson PA, Williams SJ, Kobe B (2017) Animal NLRs provide structural insights into plant NLR function. Ann Bot 119: 689-702

16. Zhang X, Dodds PN, Bernoux M (2017) What do we know about NODlike receptors in plant immunity? Annu Rev Phytopathol 55: 205-229

17. Jones JDG, Vance RE, Dangl JL (2016) Intracellular innate immune surveillance devices in plants and animals. Science 354: aaf6395-1aaf6395-8

18. Sukarta OCA, Slootweg EJ, Goverse A (2016) Structure-informed insights for NLR functioning in plant immunity. Semin Cell Dev Biol 56: 134-149

19. Baggs E, Dagdas G, Krasileva KV (2017) NLR diversity, helpers and integrated domains: making sense of the NLR IDentity. Curr Opin Plant Biol 38: 59-67

20. Cui H, Tsuda K, Parker JE (2015) Effector-triggered immunity: from pathogen perception to robust defense. Annu Rev Plant Biol 66: 6.16.25

21. Mansfield J, Genin S, Magori S, Citovsky V, Sriariyanum M, Ronald P, Dow M, Verdier V, Beer SV, Machado MA, Toth I, Salmond G, Foster GD (2012) Top 10 plant pathogenic bacteria in molecular plant pathology. Mol Plant Pathol 13: 614-629

22. Lindeberg M, Cunnac S, Collmer A (2012) Pseudomonas syringae type III effector repertoires: last words in endless arguments. Trends Microbiol 20: 199-208

23. Xin X-F, Kvitko B, He SY (2018) Pseudomonas syringae: what it takes to be a pathogen. Nat Rev Microbiol 16: 316-328

24. White FF, Potnis N, Jones JB, Koebnik R (2009) The type III effectors of Xanthomonas. Mol Plant Pathol 10: 749-766

25. Peeters N, Carrère S, Anisimova M, Plener L, Cazalé A-C, Genin S (2013) Repertoire, unified nomenclature and evolution of the type III effector gene set in the Ralstonia solanacearum species complex. BMC Genomics 14: 859

26. Khan M, Seto D, Subramaniam R, Desveaux D (2018) Oh, the places they'll go! A survey of phytopathogen effectors and their host targets. Plant J 93: 651-663

27. Selin C, de Kievit TR, Belmonte MF, Fernando WGD (2016) Elucidating the role of effectors in plant-fungal interactions: progress and challenges. Front Microbiol 7: 600

28. Anderson RG, Deb D, Fedkenheuer K, McDowell JM (2015) Recent progress in RXLR effector research. Mol Plant-Microbe Interact28: 1063-1072

29. Dean R, Van Kan JAL, Pretorius ZA, Hammond-Kosack KE, Di Pietro A, Spanu PD, Rudd JJ, Dickman M, Kahmann R, Ellis J, Foster GD 
(2012) The top 10 fungal pathogens in molecular plant pathology. Mol Plant Pathol 13: 414-430

30. Büttner D (2016) Behind the lines-actions of bacterial type III effector proteins in plant cells. FEMS Microbiol Rev 40: 894-937

31. Feng F, Zhou J-M (2012) Plant-bacterial pathogen interactions mediated by type III effectors. Curr Opin Plant Biol 15: 469-476

32. Macho AP, Zipfel C (2015) Targeting of plant pattern recognition receptor-triggered immunity by bacterial type-III secretion system effectors. Curr Opin Microbiol 23: 14-22

33. Deslandes L, Rivas S (2012) Catch me if you can: bacterial effectors and plant targets. Trends Plant Sci 17: 644-655

34. Macho AP (2016) Subversion of plant cellular functions by bacterial type-III effectors: beyond suppression of immunity. New Phytol 210: 51-57

35. Varden FA, De la Concepcion JC, Maidment JHR, Banfield MJ (2017) Taking the stage: effectors in the spotlight. Curr Opin Plant Biol 38: 25-33

36. Toruño TY, Stergiopoulos I, Coaker G (2016) Plant-pathogen effectors: cellular probes interfering with plant defenses in spatial and temporal manners. Annu Rev Phytopathol 54: 419-441

37. Banfield MJ (2015) Perturbation of host ubiquitin systems by plant pathogen/pest effector proteins. Cell Microbiol 17: 18-25

38. Üstün S, Börnke F (2014) Interaction of Xanthomonas type-III effector proteins with the plant ubiquitin and ubiquitin-like pathways. Front Plant Sci 5: 736

39. Park E, Nedo A, Caplan JL, Dinesh-Kumar SP (2017) Plant microbe interactions: organelles and the cytoskeleton in action. New Phytol 217: 1012-1028

40. Stael S, Kmiecik P, Willems P, Van Der Kelen K, Coll NS, Teige M, Van Breusegem F (2015) Plant innate immunity - sunny side up? Trends Plant Sci 20: 3-11

41. Ma K-W, Ma W (2016) Phytohormone pathways as targets of pathogens to facilitate infection. Plant Mol Biol 91: 713-725

42. Kazan K, Lyons R (2014) Intervention of phytohormone pathways by pathogen effectors. Plant Cell 26: 2285-2309

43. Shigenaga AM, Argueso CT (2016) No hormone to rule them all: interactions of plant hormones during the responses of plants to pathogens. Sem Cell Dev Biol 56: 174-189

44. Lewis LA, Polanski K, de Torres-Zabala M, Jayaraman S, Bowden L, Moore J, Penfold CA, Jenkins DJ, Hill C, Baxter L, Kulasekaran S, Truman W, Littlejohn G, Prusinska J, Mead A, Steinbrenner J, Hickman R, Rand D, Wild DL, Ott S, Buchanan-Wollaston V, Smirnoff N, Beynon J, Denby K, Grant M (2015) Transcriptional dynamics driving MAMP-triggered immunity and Pathogen Effector-Mediated immunosuppression in Arabidopsis leaves following infection with Pseudomonas syringae pv. tomato DC3000. Plant Cell 27: 3038-3064

45. Bogdanove AJ, Schornack S, Lahaye T (2010) TAL effectors: finding plant genes for disease and defense. Curr Opin Plant Biol 13: 394-401

46. Rivas S, Genin S (2011) A plethora of virulence strategies hidden behind nuclear targeting of microbial effectors. Front Plant Sci 2, 104

47. Buscaill P, Rivas S (2014) Transcriptional control of plant defence responses. Curr Opin Plant Biol 20: 35-46

48. Wu J, Van der Burgh AM, Bi G, Zhang L, Alfano JR, Martin GB, Joosten MHAJ (2018) The bacterial effector AvrPto targets the regulatory coreceptor SOBIR1 and suppresses defense signaling mediated by the receptor-like protein Cf-4. Mol Plant-Microbe Interact 31: 75-85

49. Li L, Kim P, Yu L, Cai G, Chen S, Alfano JR, Zhou J-M (2016) Activation-dependent destruction of a co-receptor by a Pseudomonas syringae effector dampens plant immunity. Cell Host Microbe 20: 504-514

50. Qin J, Zhou X, Sun L, Wang K, Yang F, Liao H, Rong W, Yin J, Chen H, Chen X, Zhang J (2018) The Xanthomonas effector XopK harbours E3 ubiquitin-ligase activity that is required for virulence. New Phytol 220: $219-231$

51. Zheng X, Wagener N, McLellan H, Boevink PC, Hua C, Birch PRJ, Brunner F (2018) Phytophthora infestans RXLR effector SFI5 requires association with calmodulin for PTI/MTI suppressing activity. New Phytol 219: 1433-1446
52. Shi X, Long Y, He F, Zhang C, Wang R, Zhang T, Wu W, Hao Z, Wang Y, Wang G-L, Ning Y (2018) The fungal pathogen Magnaporthe oryzae suppresses innate immunity by modulating a host potassium channel. PLOS Pathog 14: e1006878

53. Jwa N-S, Hwang BK (2017) Convergent evolution of pathogen effectors toward reactive oxygen species signaling networks in plants. Front Plant Sci: 8: 1687

54. Schuebel F, Rocker A, Edelmann D, Schessner J, Brieke C, Meinhart A (2016) 3'-NADP and 3'-NAADP, two metabolites formed by the bacterial type III effector AvrRxo1. J Biol Chem 291: 22868-22880

55. Sun Y, Li P, Deng M, Shen D, Dai G, Yao N, Lu Y (2017) The Ralstonia solanacearum effector RipAK suppresses plant hypersensitive response by inhibiting the activity of host catalases. Cell Microbiol 19: e12736

56. Mukaihara T, Hatanaka T, Nakano M, Oda K (2016) Ralstonia solanacearum type III effector RipAY is a glutathione-degrading enzyme that is activated by plant cytosolic thioredoxins and suppresses plant immunity. mBio 7: e00359-16

57. Eschen-Lippold L, Jiang X, Elmore JM, Mackey D, Shan L, Coaker G, Scheel D, Lee J (2016) Bacterial AvrRpt2-like cysteine proteases block activation of the Arabidopsis mitogen-activated protein kinases, MPK4 and MPK11. Plant Physiol 171: 2223-2238

58. King SRF, McLellan H, Boevink PC, ArmstrongMR, Bukharova T, Sukarta O, Win J, Kamoun S, Birch PRJ, Banfield MJ (2014) Phytophthora infestans RXLR effector PexRD2 interacts with host MAPKKK to suppress plant immune signaling. Plant Cell 26: 1345-1359

59. Teper D, Girija AM, Bosis E, Popov G, Savidor A, Sessa G (2018) The Xanthomonas euvesicatoria type III effector XopAU is an active protein kinase that manipulates plant MAP kinase signaling. PLOS Pathog 14: e1006880

60. Jin L, Ham JH, Hage R, Zhao W, Soto-Hernández J, Lee SY, Paek S-M, Kim MG, Boone C, Coplin DL, Mackey D (2016) Direct and indirect targeting of PP2A by conserved bacterial type-III effector proteins. PLOS Pathog 12: e1005609

61. Lozano-Durán R, Robatzek S (2015) 14-3-3 proteins in plant-pathogen interactions. Mol Plant-Microbe Interact 28: 511-518

62. Sun X, Greenwood DR, Templeton MD, Libich DS, McGhie TK, Xue B, Yoon M, Cui W, Kirk CA, Jones WT, Uversky VN, Rikkerink EHA (2014) The intrinsically disordered structural platform of the plant defence hub protein RPM1-interacting protein 4 provides insights into its mode of action in the host-pathogen interface and evolution of the nitrate-induced domain protein family. FEBS J 281: 3955-3979

63. Chung E-H, El-Kasmi F, He Y, Loehr A, Dangl JL (2014) A plant phosphoswitch platform repeatedly targeted by type III effector proteins regulates the output of both tiers of plant immune receptors. Cell Host Microbe 16: 484-494

64. Üstün S, Sheikh A, Gimenez-Ibanez S, Jones A, Ntoukakis V, Börnke F (2016) The proteasome acts as a hub for plant immunity and is targeted by Pseudomonas type III effectors. Plant Physiol 172: 1941-1958

65. Tomczynska I, Stumpe M, Mauch F (2018) A conserved RxLR effector interacts with host RABA-type GTPases to inhibit vesicle-mediated secretion of antimicrobial proteins. Plant J 95: 187-203

66. Du Y, Overdijk EJR, Berg JA, Govers F, Bouwmeester K (2018) Solanaceous exocyst subunits are involved in immunity to diverse plant pathogens. J Exp Bot 69: 655-666

67. De Torres-Zabala M, Littlejohn G, Jayaraman S, Studholme D, Bailey T, Lawson T, Tillich M, Licht D, Bölter B, Delfino L, Truman W, Mansfield J, Smirnoff N, Grant M (2015) Chloroplasts play a central role in plant defence and are targeted by pathogen effectors. Nature Plants 1: $1-10$

68. Caplan JL, Kumar AS, Park E, Padmanabhan MS, Hoban K, Modla S, Czymmek K, Dinesh-Kumar SP (2015) Chloroplast stromules function during innate immunity. Dev Cell 34: 45-57

69. Erickson JL, Adlung N, Lampe C, Bonas U, Schattat MH (2018) The Xanthomonas effector XopL uncovers the role of microtubules in stromule extension and dynamics in Nicotiana benthamiana. Plant J 93: 856870 
70. Tanaka S, Han X, Kahmann R (2015) Microbial effectors target multiple steps in the salicylic acid production and signaling pathway. Front Plant Sci 6: 349

71. Qin J, Wang K, Sun L, Xing H, Wang S, Li L, Chen S, Guo H-S, Zhang J (2018) The plant-specific transcription factors CBP60g and SARD1 are targeted by a Verticillium secretory protein VdSCP41 to modulate immunity. eLIFE 7: e34902

72. Chen H, Chen J, Li M, Chang M, Xu K, Shang Z, Zhao Y, Palmer I, Zhang Y, McGill J, Alfano JR, Nishimura MT, Liu F, Fu ZQ (2017) A bacterial type III effector targets the master regulator of salicylic acid signaling, NPR1, to subvert plant immunity. Cell Host Microbe 22: 777-788

73. Washington EJ, Mukhtar MS, Finkel OM, Wan L, Banfield MJ, Kieber JJ, Dangl JL (2016) Pseudomonas syringae type III effector HopAF1 suppresses plant immunity by targeting methionine recycling to block ethylene induction. Proc Natl Acad Sci USA 113: E3577-E3586

74. Gimenez-Ibanez S, Chini A, Solano R (2016) How microbes twist jasmonate signaling around their little fingers. Plants 5: 9

75. Yang L, Teixeira PJPL, Biswas S, Finkel OM, He Y, Salas-Gonzalez I, English ME, Epple P, Mieczkowski P, Dangl JL (2017) Pseudomonas syringae type III effector HopBB1 promotes host transcriptional repressor degradation to regulate phytohormone responses and virulence. Cell Host Microbe 21: 156-168

76. Boch J, Bonas U, Lahaye T (2014) TAL effectors - pathogen strategies and plant resistance engineering. New Phytol 204: 823-832

77. Verma A, Lee C, Morriss S, Odu F, Kenning C, Rizzo N, Spollen WG, Lin M, McRae AG, Givan SA, Hewezi T, Hussey R, Davis EL, Baum TJ, Mitchum MG (2018) The novel cyst nematode effector protein 30D08 targets host nuclear functions to alter gene expression in feeding sites. New Phytol 219: 697-713

78. Kong L, Qiu X, Kang J, Wang Y, Chen H, Huang J, Qiu M, Zhao Y, Kong G, Ma Z, Wang Y, Ye W, Dong S, Ma W, Wang Y (2017) A Phytophthora effector manipulates host histone acetylation and reprograms defense gene expression to promote infection. Curr Biol 27: $981-991$

79. Wei H-L, Collmer A (2018) Defining essential processes in plant pathogenesis with Pseudomonas syringae pv. tomato DC3000 disarmed polymutants and a subset of key type III effectors. Mol Plant Pathol 19: $1779-1794$

80. Brauer EK, Popescu GV, Singh DK, Calviño M, Gupta K, Gupta B, Chakravarthy S, Popescu SC (2018) Integrative network-centric appro- ach reveals signaling pathways associated with plant resistance and susceptibility to Pseudomonas syringae. PLOS Biol 16: e2005956

81. Franceschetti M, Maqbool A, Jiménez-Dalmaroni MJ, Pennington HG, Kamoun S, Banfield MJ (2017) Effectors of filamentous plant pathogens: Commonalities amid diversity. Microbiol Mol Biol Rev 81: e00066-16

82. Lo Presti L, Lanver D, Schweizer G, Tanaka S, Liang L, Tollot M, Zuccaro A, Reissmann S, Kahmann R (2015) Fungal effectors and plant susceptibility. Annu Rev Plant Biol 66: 513-545

83. De Guillen K, Ortiz-Vallejo D, Gracy J, Fournier E, Kroj T, Padilla A (2015) Structure analysis uncovers a highly diverse but structurally conserved effector family in phytopathogenic fungi. 11: e1005228

84. Petit-Houdenot Y, Fudal I (2017) Complex interactions between fungal avirulence genes and their corresponding plant resistance genes and consequences for disease resistance management. Front Plant Sci 8: 1072

85. Boutemy LS, King SRF, Win J, Hughes RK, Clarke TA, Blumenschein TMA, Kamoun S, Banfield MJ (2011) Structures of Phytophthora RXLR effector proteins. J Biol Chem 286: 35834-35842

86. Wawra S, Trusch F, Matena A, Apostolakis K, Linne U, Zhukov I, Stanek J, Koźminski W, Davidson I, Secombes CJ, Bayer P, Van West P (2017) The RxLR motif of the host targeting effector AVR3a of Phytophthora infestans is cleaved before secretion. Plant Cell 29: 1184-1195

87. Yin J, Gu B, Huang G, Tian Y, Quan J, Lindqvist-Kreuze H, Shan W (2017) Conserved RXLR effector genes of Phytophthora infestans expressed at the early stage of potato infection are suppressive to host defense. Front Plant Sci 8: 2155

88. Fawke S, Doumane M, Schornack S (2015) Oomycete interactions with plants: infection strategies and resistance principles. Microbiol Mol Biol Rev 79: 263-279

89. Wang S, McLellan H, Bukharova T, He Q, Murphy F, Shi J, Sun S, Van Weymers P, Ren Y, Thilliez G, Wang H, Chen X, Engelhardt S, Vieeshouwers V, Gilroy EM, Whisson SC, Hein I, Wang X, Tian Z, Birch PRJ, Boevink PC (2019) Phytophthora infestans RXLR effectors act in concert at diverse subcellular locations to enhance host colonization. J Exp Bot 70: 343-356

90. Whisson SC, Boevink PC, Wang S, Birch PRJ (2016) The cell biology of late blight disease. Curr Opin Microbiol 34: 127-135

91. Thordal-Christensen H, Birch PRJ, Spanu PD, Panstruga R (2018) Why did filamentous plant pathogens evolve the potential to secrete hundreds of effectors to enable disease? Mol Plant Pathol 19: 781-785

\section{Suppression of PAMP-triggered immunity (PTI) by effector proteins synthesized by phytopathogens and delivered into cells of infected plant}

\section{Anna Hetmann ${ }^{\Downarrow}$, Stanisław Kowalczyk}

Nicolaus Copernicus University, Faculty of Biology and Environmental Protection, Department of Biochemistry, 1 Lwowska St., 87-100 Torun, Poland

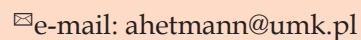

Key words: effector proteins of phytopathogens, plant basic resistance suppression, plant immune receptors NB-LRR/NLR

\section{ABSTRACT}

Plant immunity is constituted by multilayered system involving two intertwined lines of defence: a first level of immunity termed PAMPtriggered immunity (PTI) or basal resistance, and a second layer of plant defence, called effector-triggered immunity (ETI). The second line of defence depends on the ability of the plant to recognize phytopathogen-synthesized effector proteins delivered into host plant cells. The effector proteins employ common as well as pathogen-specific strategies to disturb plant immunity and to promote pathogen survival and favor their multiplication. They target pattern-recognition receptors (PRRs) and key components in the PTI signaling pathways, as well as, they interfere with many cellular processes including vesicle transport, cytoskeleton reorganization, proteasome-dependent protein degradation, phytohormone biosynthesis and signaling, and gene expression. This results in effector-triggered susceptibility (ETS). However, in some cases, pathogen effectors are recognized by plant intracellular immune receptors NB-LRR/NLR that identify effector proteins. Conformational changes in the NB-LRR/NLR immune receptors accompanying the recognition of the effector proteins activate intracellular signaling pathways initiating a whole range of defence responses that form the second line of local defence. 